\title{
Assessing impacts of agricultural water interventions in the Kothapally watershed, Southern India
}

\author{
Kaushal K. Garg, ${ }^{1 *}$ Louise Karlberg, ${ }^{2}$ Jennie Barron, ${ }^{2}$ Suhas P. Wani ${ }^{1}$ and Johan Rockstrom ${ }^{2}$ \\ ${ }^{1}$ Resilient DryLand Systems, International Crops Research Institute for the Semi-Arid Tropics (ICRISAT), Patancheru 502 324, Andhra Pradesh, \\ India \\ ${ }^{2}$ Stockholm Resilience Centre, Stockholm Environment Institute (SEI), Kräftriket 2B, 10691 Stockholm, Sweden
}

\begin{abstract}
:
The paper describes a hydrological model for agricultural water intervention in a community watershed at Kothapally in India, developed through integrated management and a consortium approach. The impacts of various soil and water management interventions in the watershed are compared to no-intervention during a 30-year simulation period by application of the calibrated and validated ARCSWAT 2005 (Version 2.1.4a) modelling tool. Kothapally receives, on average, $800 \mathrm{~mm}$ rainfall in the monsoon period. $72 \%$ of total rainfall is converted as evaporation and transpiration (ET), $20 \%$ is stored by groundwater aquifer, and $8 \%$ exported as outflow from the watershed boundary in current water interventions. ET, groundwater recharge and outflow under no-intervention conditions are found to be 64,9 , and $19 \%$, respectively. Check dams helped in storing water for groundwater recharge, which can be used for irrigation, as well minimising soil loss. In situ water management practices improved the infiltration capacity and water holding capacity of the soil, which resulted in increased water availability by 10-30\% and better crop yields compared to no-intervention. Water outflows from the developed watershed were more than halved compared to no-intervention, indicating potentially large negative downstream impacts if these systems were to be implemented on a larger scale. On the other hand, in the watershed development program, sediment loads to the streams were less than one-tenth. It can be concluded that the hydrological impacts of large-scale implementation of agricultural water interventions are significant. They result in improved rain-fed agriculture and improved productivity and livelihood of farmers in upland areas while also addressing the issues of poverty, equity, and gender in watersheds. There is a need for case-specific studies of such hydrological impacts along with other impacts in terms of equity, gender, sustainability, and development at the mesoscale. Copyright (C) 2011 John Wiley \& Sons, Ltd.
\end{abstract}

KEY WORDS hydrological modelling; SWAT; resilience; watershed management; semi arid tropics; rain-fed farming; hydrological impacts; water balance

Received 22 October 2010; Accepted 8 April 2011

\section{INTRODUCTION}

Degradation of agro-ecosystems and declining sustainability are major concerns for agricultural development in many poor regions of India where rural livelihoods depend directly on management of land and water resources (Reddy et al., 2007). In recent years, it has been realized that rain-fed agriculture, which was almost entirely neglected during the green revolution in the 1970s, also has remarkable scope for agricultural development. The Indian collaborative initiative of watershed management programmes has been ongoing in various forms for the last 30 years (Wani et al., 2008). The main aim is to enhance rural livelihoods and wellbeing, recognising the value of well-managed water and land resources. This concept ties together the biophysical notion of a watershed as a hydrological unit with the social aspect of community and its institutions for building resilience in agriculture by sustainable management of land, water, and other resources (Reddy et al., 2007).

\footnotetext{
* Correspondence to: Kaushal K. Garg, Resilient DryLand Systems, International Crops Research Institute for the Semi-Arid Tropics (ICRISAT), Patancheru 502 324, Andhra Pradesh, India. E-mail: k.garg@cgiar.org
}

To date, in India, an estimated 88.5 million ha of land is assumed to have been included in this initiative (Wani et al., 2008). The watershed management initiative has not only transformed livelihoods and enhanced resource management, but has also changed micro- to small-scale $\left(0 \cdot 1-10 \mathrm{~km}^{2}\right)$ watershed hydrological characteristics. As yet, there is little systematic quantification of how much impact these field-to-community-scale soil and water conservation measures may have had on watershed water balance, water quantity, and quality.

Resilience is the capacity of a system to absorb disturbance and still retain its basic function and structure (Walker and Salt, 2006). Agricultural systems, and in particular rain-fed agriculture in the semi-arid tropics, are highly vulnerable to various types of climatic and socio-economic shocks. In semi-arid and dry subhumid agro-ecosystems rainfall variability generates dry spells (short periods of water stress during critical growth stages) almost every rainy season (e.g. Barron et al., 2003; Rao et al., 2006; Singh and Ranade, 2009). One purpose of the watershed development programmes is to reduce the water-related risks in rain-fed agriculture by improving local soil water balance. This can be achieved by implementing both in situ water harvesting practices 
and structures for increased groundwater recharge that is subsequently used for supplementary irrigation from dug and bore wells. The watershed development programmes leverage and strengthen desirable development by improving capacity to cope with inherent dry spells and reducing their negative impacts on crop yields, and subsequently, livelihoods.

Soil erosion is one of the most serious problems in India (Sharda et al., 2010). Watershed development programmes in India in 1980 started primarily with aim to reduce soil erosion in agricultural land and to control gully formation (Joshi et al., 2005, 2009). Soil erosion causes land degradation upstream and increases sediment loads in downstream water bodies (Yang et al., 2003). It is estimated that the annual loss rate of reservoir storage capacity due to sedimentation is about $0.5-1.0 \%$ in most of the river basins in India and elsewhere (Walling, 2007). Osman Sagar reservoir has had its storage capacity reduced by about 12 per cent between 1973 and 1988 due to excessive sediment loading (Hyderabad Metropolitan Water Supply and Sewerage Board). This amount is equivalent to $15 \mathrm{t}$ soil/ha/year erosion from the entire catchment area, and corresponds to the loss of approximately $1 \mathrm{~cm}$ soil every decade from the catchment area.

In water-stressed areas, concern has been raised about potential downstream implications from large-scale adoption of upstream water management techniques (e.g. Calder, 1999). However, the downstream impacts on stream flow from small-scale water storage systems have been shown to be very limited, even with large-scale implementation (Evenari et al., 1971; Schreider et al., 2002; Sreedevi et al., 2006). In fact, investment in soil and water management can result in reduced sedimentation which has a positive impact on the water quality downstream. Owing to the nonlinear relationship between evapotranspiration and yield in low-yielding systems (i.e. $2 \mathrm{t} \mathrm{ha}^{-1}$ for tropical grains - Rockström, 2003), the yield increase from $1 \mathrm{t} \mathrm{ha}^{-1}$ to $2 \mathrm{t} \mathrm{ha}^{-1}$ does not necessarily have to entail a large upstream water appropriation, as this may be achieved by so-called vapour shift (from unproductive evaporation loss, to biomass productive transpiration). Thus, the downstream effects may be less significant than hitherto believed. On the other hand, in closed and closing basins, more water is used than is renewably available, at least during parts of the year, which constrains opportunities for agricultural water management (Molden et al., 2001; Molle, 2003). India will continue to rely on careful water and land management to further enhance agricultural production and rural livelihoods. The management of water from farmers' fields to basins levels will need to improve in the future, to meet demands on water resources in various sectors, considering that rainfall will continue to be unpredictable at best, and potentially reduced in worst-case scenarios.

Here, we present results from a study of the Kothapally watershed, in the Musi sub-basin of the Krishna basin. This represents a typical Indian semi-arid microwatershed in transformation. The impacts of various soil and water management interventions carried out through the watershed are compared to the no-intervention state during a 30-year simulation period by application of the calibrated and validated ARCSWAT 2005 (Version 2.1.4a) modelling tool. The aim is to analyse the impact of in situ and ex situ agricultural water management on: (1) the partitioning of water balance components such as soil moisture, groundwater recharge, and outflows from the watershed; (2) yields; and (3) soil loss and sedimentation loads to the river. This paper focuses especially on water balance and flow impacts during extreme events, which may represent the future climate change scenarios for the location.

\section{STUDY AREA: KOTHAPALLY WATERSHED}

The Kothapally watershed, is located at $17^{\circ} 22^{\prime} \mathrm{N}$ latitude, $78^{\circ} 07^{\prime} \mathrm{E}$ longitude, and about $550 \mathrm{~m}$ a.m.s.l. in the Ranga Reddy District of Andhra Pradesh, India. This watershed is part of the Musi sub-basin of the Krishna River basin, and is situated approximately $25 \mathrm{~km}$ upstream of the Osman Sagar reservoir (Figure 1). The Krishna is one of the largest rivers in southern India and the basin lies within the states of Maharashtra, Karnataka, and Andhra Pradesh (Immerzeel et al., 2008.). There are three major reservoirs in the Musi sub-basin: Osman Sagar (OS), Himayat Sagar (HS), and Musi Medium (MM). The geographical land area of the Kothapally village (political boundary) is 465 ha. The hydrological delineated microwatershed of Kothapally used for this study encompasses 293 ha.

Rainfall is highly erratic, both in terms of total amount and its distribution over time. Mean annual rainfall at Kothapally is $860 \mathrm{~mm}$ with about $85 \%$ falling from June to October. Rainfall data shows that a total of $446-1087 \mathrm{~mm}$ (average $741 \mathrm{~mm}$ ) precipitation was received during the monsoon period (Jun-Oct) from years 2000 to 2008. Maximum rainfall intensity varied from $39 \mathrm{~mm} /$ day (in 2002) to $302 \mathrm{~mm} /$ day (in 2000), the latter representing an extreme event. The number of rainy days during the monsoon period was 63 out of a total of 150 on average. Rainfall data shows that dry spells longer than 5-7 days are very common and occur several times (3-8 times) per season, whereas, 10-15 days or longer dry spell also may occur during the monsoon period.

Soils have been classified as Vertisols with shallow to medium soil depth between 10 and $90 \mathrm{~cm}$. The water holding capacity is medium to low, and the soil organic carbon content is between 0.40 and $2.27 \%$ (Table I). In the Kothapally watershed, $95 \%$ of the area is under continuous cultivation. About $30-40 \%$ of this is under full or supplemental irrigation during some part of the year if water is accessible. The total population of the community is 1492 individuals belonging to about 270 cultivating and 4 non-cultivating families (Shiferaw et al., 2002), and the average land-holding per household is about 1.4 ha. There is no further potential for agricultural expansion, but only for intensification on existing land. 
IMPACTS OF AGRICULTURAL WATER INTERVENTIONS IN A MICRO-WATERSHED

Table I. Model parameterisation. Initial and final values given before and after calibration. (Data in parenthesis show minimum to maximum range of parameter value)

\begin{tabular}{|c|c|c|c|c|}
\hline Variable (unit) & $\begin{array}{l}\text { Parameter in } \\
\text { SWAT }\end{array}$ & Initial value & Final Value & Source \\
\hline Sand content $(\%)$ & SAND & - & $47(18-79)$ & Measured \\
\hline Silt content $(\%)$ & SILT & - & $22(11-30)$ & Measured \\
\hline Clay content $(\%)$ & CLAY & - & $31(5-61)$ & Measured \\
\hline Gravel fraction (\%) & ROCK & - & $20(5-48)$ & Measured \\
\hline Bulk density $\left(\mathrm{g} \mathrm{cm}^{-3}\right)$ & SOL_BD & - & $1 \cdot 3(1 \cdot 1-1 \cdot 6)$ & Measured \\
\hline $\begin{array}{l}\text { Available water content ( } \mathrm{mm} \\
\mathrm{H}_{2} \mathrm{O} / \mathrm{mm} \text { soil) }\end{array}$ & SOL_AWC & - & $0.26(0 \cdot 17-0.33)$ & Measured \\
\hline Organic carbon (\%) & SOL_CBN & - & $1.04(0.44-2 \cdot 27)$ & Measured \\
\hline Soil depth $(\mathrm{mm})$ & SOL_Z & - & $420(50-930)$ & Surveyed \\
\hline $\begin{array}{l}\text { Saturated hydraulic conductivity } \\
(\mathrm{mm} / \mathrm{h})\end{array}$ & SOL_K & - & $2 \cdot 2-10 \cdot 8$ & $\begin{array}{l}\text { Estimated by } \\
\text { pedo-transfer function } \\
\text { (Schaap et al., 2001) }\end{array}$ \\
\hline Curve number $(-)$ & $\mathrm{CN}$ & 70 & $70-80$ & $\begin{array}{l}\text { Based on previous study } \\
\quad \text { (Pathak et al., 2002) }\end{array}$ \\
\hline $\begin{array}{l}\text { Hydraulic conductivity of the } \\
\text { reservoir bottom }(\mathrm{mm} / \mathrm{h})\end{array}$ & RES_K & $8 \cdot 0$ & $4 \cdot 0-20 \cdot 0$ & Calibrated \\
\hline Groundwater revap coeff. $(-)$ & GW_REVAP & 0.02 & $0 \cdot 1-0.7$ & Calibrated \\
\hline $\begin{array}{l}\text { Threshold depth of water for } \\
\text { revap in shallow aquifer ( } \mathrm{mm} \\
\mathrm{H}_{2} \mathrm{O} \text { ) }\end{array}$ & REVAP_MN & 1 & $0 \cdot 3-21 \cdot 0$ & Calibrated \\
\hline $\begin{array}{l}\text { Threshold depth of water in the } \\
\text { shallow aquifer required to } \\
\text { return flow }\left(\mathrm{mm} \mathrm{H}_{2} \mathrm{O}\right)\end{array}$ & GWQMN & 0 & $200-500$ & Calibrated \\
\hline Groundwater delay time (days) & GW_DELAY & 31 & 2 & Calibrated \\
\hline Channel erodibility factor $(-)$ & CH_EROD & $0 \cdot 0$ & 0.5 & Assumed \\
\hline Channel cover factor $(-)$ & CH_COV & $0 \cdot 0$ & 0.5 & Assumed \\
\hline $\begin{array}{l}\text { USLE equation support practice } \\
\text { factor }(-)\end{array}$ & USLE_P & $1 \cdot 0$ & $0 \cdot 6$ & Calibrated \\
\hline $\begin{array}{l}\text { Maximum potential leaf area } \\
\text { index }(-)\end{array}$ & BLAI & & $4 \cdot 5$ & From Krieg, 2000 \\
\hline $\begin{array}{l}\text { Lower limit of harvest index } \\
\qquad((\mathrm{kg} / \mathrm{ha}) /(\mathrm{kg} / \mathrm{ha}))\end{array}$ & WSYF & & 0.05 & Calibrated \\
\hline Harvest index $(-)$ & HVSTI & & $0 \cdot 5$ & $\begin{array}{l}\text { From Heuer and Nadler, } \\
\quad 2000\end{array}$ \\
\hline $\begin{array}{l}\text { Ex situ interventions developed } \\
\text { in watershed since } 1999 \\
\text { onwards }\left(\mathrm{m}^{3}\right)\end{array}$ & RES_VOL & - & 13150 & Measured \\
\hline Surface area of ex situ int. $\left(\mathrm{m}^{2}\right)$ & RES_ESA & - & 13850 & Measured \\
\hline
\end{tabular}

The watershed development program in Kothapally started in 1999. A range of agricultural water management initiatives have been adopted since it started, both at community and individual farm levels. The most common in situ interventions are contour and graded bunds in the fields, which reduce travel distance and minimize the velocity of generated runoff and allow more water to percolate into the fields. This practice creates an opportunity to accumulate surface runoff along the contour line, and also protects soils from erosion. Check dams on the rivers and other ex situ practices reduce peak discharge and harvest a substantial amount of runoff, which increases groundwater recharge. At the same time, these dams trap sediments which protect the river ecosystems further downstream. The water in the check dams cannot be used directly for irrigation, and the stored water is allowed to recharge the groundwater aquifer by percolation. Instead, groundwater from open wells is used to irrigate crops.

\section{METHODOLOGY}

\section{Model description}

The Soil and Water Assessment Tool (SWAT) is a well recognized model for predicting water flows, sediment loss, and nutrient balances in complex watershed, basin, and even continental-scale assessments with varying soils, land use, and management conditions (Arnold et al., 1998; Srinivasan et al., 1998; Arnold and Fohrer, 2005; Gassman et al., 2007). The model integrates the principal hydrological processes, soil and nutrient transport, and vegetative growth on a spatial and temporal frame, using a daily to an annual time scale. Regressionbased functions describe the relationship of input and output in SWAT, and a number of static and dynamic variables are created to represent the system boundary and its function/process. Large watersheds are divided into smaller units based on stream network, soil, and land use information. Rainfall is divided into different 


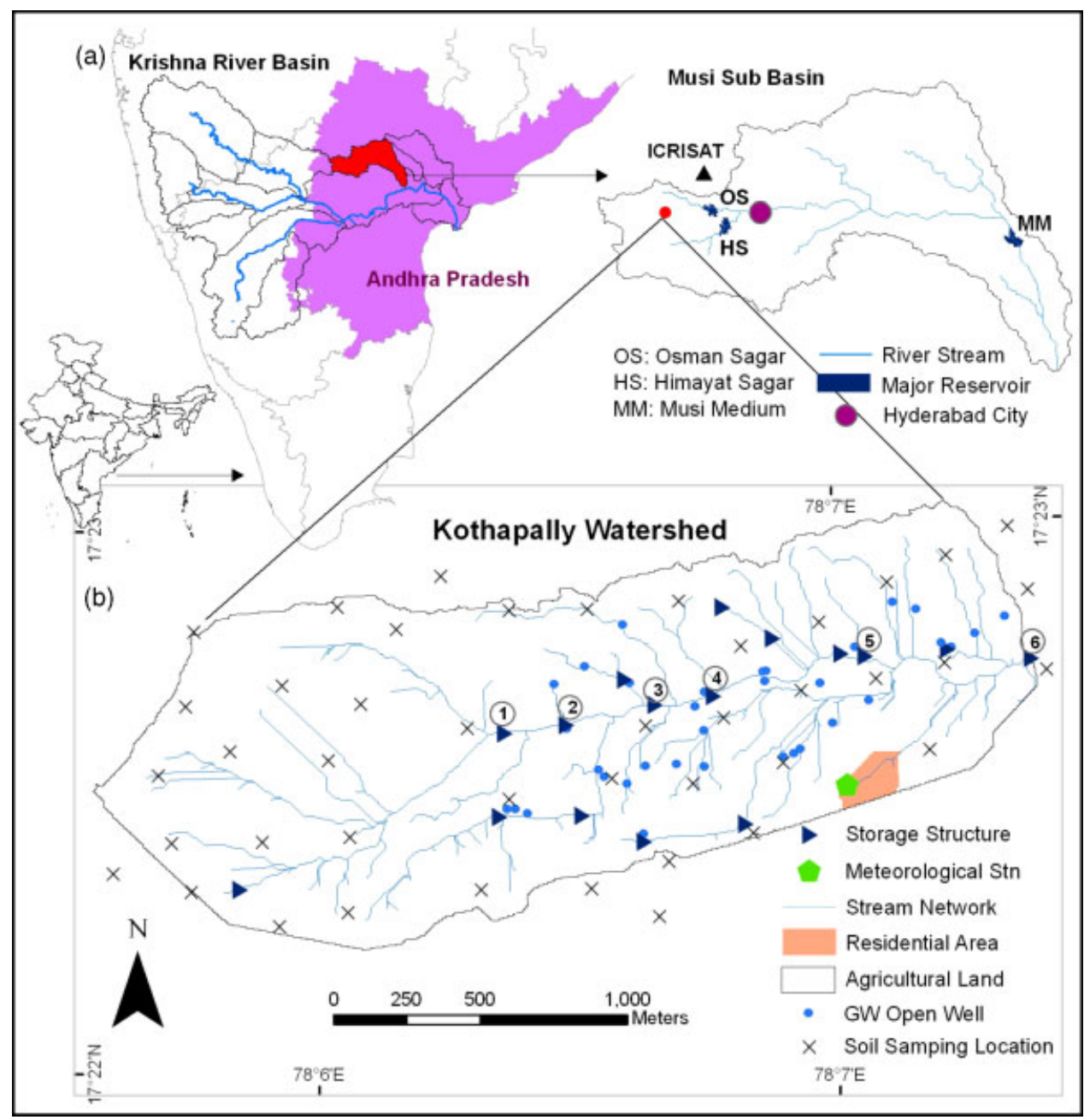

Figure 1. (a) Location of Kothapally watershed in Musi sub-basin of Krishna river basin, including main reservoirs, ICRISAT, and Hyderabad City; (b) Stream network, location of storage structures, open wells, meteorological station, soil sampling locations, and residential area in Kothapally watershed

components, which include evaporation, surface runoff, infiltration, plant uptake, lateral flow, and groundwater recharge. Water in each sub-watershed is stored as: (1) snow at soil surface (not relevant here), (2) moisture content at various soil layers, (3) shallow aquifer, and (4) deep aquifer (King et al., 1999). Surface runoff from daily rainfall is estimated with a modification of the soil conservation service (SCS) curve number $(\mathrm{CN})$ method from United States Department of Agriculture-Soil Conservation Service (USDA SCS) (Arnold and Allen, 1996; Neitsch et al., 2005) and peak runoff rates using a modified rational method (Neitsch et al., 2005). Water, soil, and nutrients are routed from sub-watershed outlet to stream channels.

The Penman-Monteith (Monteith, 1965) method was chosen for calculating potential evapotranspiration (PET) in the present study. SWAT simulates plant growth by using the generic crop growth module from the EPIC (Erosion Productivity Impact Calculator) model (Neitsch et al., 2005). The crop growth module first calculates the plant growth under optimal conditions, and then computes the actual growth under stresses inferred by water, temperature, nitrogen, and phosphorous deficiency
(Luo, et al., 2008). Sediment yield is estimated for each sub-watershed with the Modified Universal Soil Loss Equation (MUSLE) (Williams, 1975). SWAT first estimates runoff volume and peak runoff rate, which are used to calculate the runoff erosive energy and sediment load (Shen et al., 2009). A detailed description of this model is given by Neitsch et al., 2005.

\section{Input data and model setup}

SWAT requires three basic files for delineating the watershed into sub-watersheds: a Digital Elevation Model (DEM), a soil map, and a land use/land cover (LULC) map. We generated a detailed DEM $(10 \mathrm{~m} \times 10 \mathrm{~m}$ resolution) from a topographic survey using a Nikon total station (DTM-851) survey instrument, by taking 4252 survey observations in an area covering approximately 300 ha. Stream channels have been tracked using a GPS for further verification of the flow network. The total watershed area has been divided into 110 sub-units for study purpose. A soil map of Kothapally watershed was prepared by collecting soil samples on every 250$\mathrm{m}$ grid in the watershed (Figure 1). Undisturbed soil cores (43 cores) were taken for measuring bulk density. 
Table II. Various inputs/data used with different time intervals during model calibration, validation and scenarios development

\begin{tabular}{|c|c|c|c|}
\hline & Source of meteorological data & Time period & $\begin{array}{l}\text { Model performance } \\
\text { assessed/outputs }\end{array}$ \\
\hline Model calibration & Kothapally watershed data & 2000-2009 & $\begin{array}{l}\text { (i) Flow and sediment loss at } \\
\text { watershed outlet between } 2002 \text { and } \\
2007 \text { on daily time interval (total } 53 \\
\text { runoff events); } \\
\text { (ii) Reservoir stage data of } 2009 \text {; } \\
\text { (iii) Crop yield data between } 2005 \text { and } \\
2008\end{array}$ \\
\hline Model validation & Kothapally watershed data & 2000-2009 & $\begin{array}{l}\text { (i) Measured water table in open wells } \\
\text { (ii) Literature values/past } \\
\text { studies/secondary information }\end{array}$ \\
\hline $\begin{array}{l}\text { Validation of No Int. } \\
\text { Scenario }\end{array}$ & ICRISAT data & 1984-1999 & $\begin{array}{l}\text { Monthly and annual inflow at Osman } \\
\text { Sagar reservoir }\end{array}$ \\
\hline $\begin{array}{l}\text { Simulation/Scenario } \\
\text { development }\end{array}$ & ICRISAT data & $1978-2008$ & Results analysed \\
\hline
\end{tabular}

Other physical properties such as texture, gravel content, organic carbon, field capacity, and permanent wilting point were estimated in the laboratory. Soil depth information was also collected by interviewing farmers at 60 different locations. Estimated soil parameters were derived for all 110 sub-units by inverse distance weighing (IDW) interpolation technique in Arc-GIS. Table I summarizes details of soil physical properties of the Kothapally watershed. Agriculture covers almost 97\% area in the watershed, while the rest is classified as residential area (Figure 1).

A meteorological station (shown in Figure 1) was installed in the Kothapally watershed in the year 2000. Daily data of rainfall, wind speed, relative humidity, solar radiation, and air temperature were monitored and given as inputs to the model. Locations of check dam storage structures were taken using GPS readings and their surface area and storage volume were measured. Structures with a storage capacity equal to or greater than $350 \mathrm{~m}^{3}$ were represented as separate reservoirs in SWAT, while smaller structures were represented as one single unit (reservoir) at every stream/channel in the model. All together, 14 reservoirs were created (shown in Figure 1) to represent existing reservoirs and other ex situ interventions; their year of construction and other salient features (i.e. surface area and total storage capacity) were provided as inputs into the model (Table I). A total number of 32 open wells are the source for irrigation in approximately one-third of the land of the Kothapally watershed, and are shown in Figure 1.

Crop management parameters in SWAT were based on farmers' normal practice in Kothapally. The crop pattern is dominated by cotton planted in June and harvested in December. Tillage was in the last week of May and nitrogen and phosphorus fertilizers $(\mathrm{N}$ and $\mathrm{P}$, each $50 \mathrm{~kg}$ $\mathrm{ha}^{-1}$ ) were applied on the 15 th of June at the time of crop planting. A second doze of fertilizer ( $\mathrm{N}$, each $\left.50 \mathrm{~kg} \mathrm{ha}^{-1}\right)$ was applied to the plants in middle stage of crop growth 120 days after crop planting. Those sub-watersheds with access to groundwater for irrigation from open wells were identified in the model. These areas received $100 \mathrm{~mm}$ of irrigation water on three occasions in the model: on 15 Oct, $15 \mathrm{Nov}$, and $15 \mathrm{Dec}$, respectively. The amount of irrigation and frequency are decided based on farmers' practice in general. However, the exact date of water application may vary from field to field in real situations. The Arc SWAT was run on daily basis for the calibration and validation period from 2000 to 2009 . Thus, the calibration was done for the time period when Kothapally had already developed both in situ and ex situ agricultural water management interventions.

\section{Model parameterisation and calibration}

Table II summarizes various input data used during different time intervals for model calibration, validation, and scenario development. In the present study, the model was calibrated for the Kothapally watershed based on: (1) discharge at outlet, (2) reservoir-volume data, (3) sediment flow at outlet, and (4) crop yield. The model was validated using groundwater (water table) data and comparing selected estimated outputs (water productivity and specific yield) with literature values and farmers' knowledge. Discharge and soil loss data was available for 53 runoff events monitored between 2002 and 2007 at the watershed outlet (the outlet of check dam No 6 in Figure 1). The level in reservoirs was monitored daily at six different locations between June and November 2009, and later converted into dam water volumes. Check dam number $1,2,3$, and 4 were located in a series across the main channel; check dam No 5 existed at the outlet of a mini-watershed; and check dam No 6 was located at the outlet of the Kothapally watershed. Yield data for the cotton crop was available for eight farmers' fields between year 2000 and 2006 and was used to parameterize the crop growth.

Parameterisation and calibration of water flow: Initially, parameters responsible for surface runoff and base flow were identified by doing a sensitivity analysis and from available literature (Lenhart et al., 2002; Holvoet 
et al., 2005; Muleta and Nicklow, 2005; Abbaspour et al., 2007; Arabi et al., 2007; Barlund et al., 2007; Kannan et al., 2007; Schuol et al., 2008). Four parameters, GW_DELAY, GW_REVAP, REVAP_MN, and GWQMN were found to be the most sensitive for generating return flow (also called base flow); and the parameters $\mathrm{CN}$ and SOL_K (saturated hydraulic conductivity of soil) for generating surface runoff. GW_DELAY (groundwater delay time) is the travel time required for water to join a shallow aquifer, moving across the vadose zone; GW_REVAP (Groundwater 'revap' coefficient) is a factor which controls water movement from the shallow aquifer to the overlying unsaturated layers; REVAP_MN is the threshold limit of shallow aquifer required to move water for 'revap' or percolate to the deep aquifer recharge; and GWQMN is the threshold depth of water in the shallow aquifer required for return flow to occur (Neitsch et al., 2005). Thus, these parameters were manually changed to match time of concentration, amount of reservoir inflow, and gauge discharge with measured data. Table I shows the list of various parameters, their initial/default, and final values before and after calibration, respectively.

The $\mathrm{CN}$ varies nonlinearly with the moisture content of the soil and drops as the soil approaches the wilting point and increases to near 100 as the soil approaches saturation (Kim and Lee, 2008). The parameter SOL_K (saturated hydraulic conductivity) is a measure of ability of the water to move into the soil. $\mathrm{CN}$ values for the Kothapally watershed were taken from previous field studies made by Pathak et al., 2002 and assigned directly into the model. Saturated hydraulic conductivity was derived from measured soil physical properties using pedo-transfer function (Schaap et al., 2001).

After assigning $\mathrm{CN}$ and SOL_K values, parameters determining base flow were adjusted by increasing the GWQMN and GW_REVAP value to $100 \mathrm{~mm}$ and $0 \cdot 1$, respectively, and decreasing REVAP_MN value by $5 \mathrm{~mm}$ in every step, respectively or vice versa. Further, the parameter GW_DELAY was adjusted from its default value by matching the shape of simulated hydrograph with measured data. Moreover, the hydraulic conductivity at the reservoir bottom (RES_K) was adjusted by bringing the simulated percolation rate close to measured percolation data at various reservoir locations. The calibration is first performed at upstream locations and continued downwards in the watershed.

Parameterisation and calibration of sediment load: During the calibration, the amount of soil loss from the watershed was compared with measured data. Three parameters-USLE_P, CH_EROD, and CH_COV-were found to be sensitive to sediment load, and have also been reported in other studies (Lenhart et al., 2002; Abbaspour et al., 2007). USLE_P (support practice factor) is the measure of land management (in situ watershed management) practice; $\mathrm{CH}$ EROD (channel erodibility factor) is conceptually similar to the soil erodibility factor used in the USLE equation and shows the erodibility of the stream channel (Neitsch et al., 2005); CH_COV (channel cover factor) indicates stability (or degradation) of stream channel due to vegetative cover (Neitsch et al., 2005). The parameters, $\mathrm{CH}$ EROD and $\mathrm{CH}_{-} \mathrm{COV}$ were assumed to be 0.5 (kept into middle range), and USLE_P was adjusted manually to match sediment load with measured data (Table I).

Parameterisation and calibration of crop yield: Average cotton yields obtained from different sub-units were compared with measured yields. To parameterize cotton growth, the literature values of parameters HVSTI, BLAI, and WSYF were assigned into model. HVSTI (potential harvest index) defines the fraction of plant biomass harvested in ideal growing conditions; BLAI (maximum potential leaf area index) is an important parameter that influences the photosynthesis and growth of the plant; WSYF (lower limit of harvest index) represents the lowest harvest index expected due to water stress (Neitsch et al., 2005). Values for BLAI and HVSTI were taken from the literature (Krieg, 2000; Heuer and Nadler, 2000), and WSYF was adjusted by comparing measured and simulated cotton yield (Table I).

\section{Parameterisation of scenarios of agricultural water management interventions}

As described before, in situ and ex situ interventions together have been implemented in the Kothapally watershed since the beginning of watershed development programme. Contour and graded bunding, broad beds, and furrow practices were developed (in situ practices) into farmers' fields; pits were excavated and check dams were constructed (ex situ practices) across the stream network. Implemented water management practices in Kothapally (at present state) are called as maximum Intervention practices (Max Int.). Different water management scenarios were developed using the calibrated model setup to understand individual impacts of in situ or ex situ watershed intervention on watershed hydrology. Thus, four scenarios of agricultural water management interventions were analysed:

- Max Int: In situ + ex situ; i.e. current state with maximized agricultural water management interventions

- In situ: In situ only

- Ex situ: Ex situ only

- No Int: No in situ + no ex situ; i.e. the 'degraded' state of the watershed prior to 1999.

Meteorological data of Kothapally watershed originally used for model calibration and validation is replaced by ICRISAT (Lat $17.53^{\circ} \mathrm{N}$ and Long $78.27^{\circ} \mathrm{E}$; Figure 1) meteorological data set during scenario development. ICRISAT meteorological data of 31 years from the period 1978 to 2008 (Table II) was used for assessing long-term impacts on water balance partitioning, as well as potential downstream impacts of water flow and sediment flows. Prior to that, Kothapally and the ICRISAT rainfall data was compared for a known period between 2000 and 
Table III. Changes made in baseline parameters to represent No In situ practice

\begin{tabular}{|c|c|c|c|c|}
\hline Variables & $\begin{array}{l}\text { Parameter in } \\
\text { SWAT }\end{array}$ & $\begin{array}{l}\text { Parameter value } \\
\text { in base line }\end{array}$ & $\begin{array}{l}\text { Change made to represent } \\
\text { no in situ practice }\end{array}$ & Source \\
\hline Curve number $(-)$ & $\mathrm{CNOP}$ & $\mathrm{CN}$ & $\mathrm{CN}+6$ & $\begin{array}{l}\text { From Arabi et al., 2007; Ullrich and } \\
\quad \text { Volk, 2009; Mazdak et al., } 2008\end{array}$ \\
\hline $\begin{array}{l}\text { Available water capacity } \\
\left.\text { ( } \mathrm{mm} \mathrm{H}_{2} \mathrm{O} / \mathrm{mm} \text { soil }\right)\end{array}$ & AWC & AWC & 0.75 AWC & $\begin{array}{l}\text { Based on long-term field experiment at } \\
\text { ICRISAT, } \\
\text { Sahrawat et al., } 2010\end{array}$ \\
\hline $\begin{array}{l}\text { Manning's roughness } \\
\text { coeff. for overland } \\
\text { flow }(-)\end{array}$ & $\mathrm{OV} \_\mathrm{N}$ & $0 \cdot 14$ & $0 \cdot 05$ & From Neitsch et al., 2005 \\
\hline $\begin{array}{l}\text { USLE support practice } \\
\text { factor }(-)\end{array}$ & USLE_P & $0 \cdot 6$ & $1 \cdot 0$ & From Neitsch et al., 2005 \\
\hline $\begin{array}{l}\text { Groundwater revap } \\
\text { coefficient }(-)\end{array}$ & GW_REVAP & $X=0 \cdot 1-0 \cdot 7$ & $X^{\prime}=X-0 \cdot 5 \quad X$ & $\begin{array}{l}\text { Validated by comparing Osman Sagar } \\
\text { inflow }\end{array}$ \\
\hline $\begin{array}{l}\text { Threshold depth of water } \\
\text { for revap in shallow } \\
\text { aquifer }\left(\mathrm{mm} \mathrm{H}_{2} \mathrm{O}\right)\end{array}$ & REVAP_MN & $Y=0 \cdot 3-21$ & $Y^{\prime}=Y+30$ & $\begin{array}{l}\text { Validated by comparing Osman Sagar } \\
\text { inflow }\end{array}$ \\
\hline $\begin{array}{l}\text { Threshold depth of water } \\
\text { in the shallow aquifer } \\
\text { required to return flow } \\
\left(\mathrm{mm} \mathrm{H}_{2} \mathrm{O}\right)\end{array}$ & GWQMN & $Z=200-500$ & $Z^{\prime}=Z-100$ & $\begin{array}{l}\text { Validated by comparing Osman Sagar } \\
\text { inflow }\end{array}$ \\
\hline
\end{tabular}

2009, and a good correlation was found on the daily $(r=0.86)$ and monthly $(r=0.94)$ time scale.

Parameterisation without in situ management: To represent conditions without in situ practices (the No Intervention (No Int.) and ex situ scenarios), a number of parameters were changed from their baseline value and presented in Table III. Parameter values changed related to surface runoff, water holding capacity, groundwater recharge, and sediment loading. Surface runoff is sensitive to changes in the $\mathrm{CN}$ parameter. Literature suggests that $\mathrm{CN}$ values should be changed by 5-6 units to represent in situ agricultural water management interventions such as contour and graded bunding in agricultural fields (Arabi et al., 2007; Arabi et al., 2008; Ullrich and Volk, 2009). Second, soil typically washes away and subsoil is exposed in unmanaged land (Lal, 1999). Such soils normally hold less organic carbon and have poor water holding capacity (Murdock and Frye, 1983; Lal, 1999). For instance, a study of Kentucky Maury and Crider soils showed that the plant's available water holding capacity decreased from 29 to $24 \%$ in the Maury soil, and from 24 to $20 \%$ in the Crider soil because of erosion (Murdock and Frye, 1983).

Long-term experiments (1975-1998) of ICRISAT (in a small 2.5-16 ha Vertisol watershed at Patancheru, Andhra Pradesh, India) showed that implementation of soil and water conservation practices and integrated nutrient management made a favourable impact on soil physical and chemical properties in watersheds. Bulk density in the top layer was reduced from 1.4 to $1.2 \mathrm{gm} \mathrm{cm}^{-3}$; air filled porosity increased from 32 to $41 \%$, cumulative infiltration (in $1 \mathrm{~h}$ ) increased from 264 to $347 \mathrm{~mm}$; and organic $\mathrm{C}$ and total $\mathrm{N}$ content were also significantly higher in the soil (0-120 cm depth) under improved management (broad-bed and furrow + nutrients) compared to a traditionally managed field, respectively (Wani et al.,
2003; Sahrawat et al., 2010). Thus, the soil depth was kept constant but the AWC value was reduced to $25 \%$ to represent without in situ management in the present modelling. Third, Manning's roughness coefficient was changed from 0.14 to 0.05 as suggested by Neitsch et al. (2005) for unmanaged land. Fourth, the USLE support practice factor (USLE_P, for sediment loading) was changed from 0.6 to 1.0 to represent the no in situ condition. USEL_P is defined as ratio of soil loss with a specific support practice to the corresponding loss with up-anddown slope culture (i.e. unmanaged land) (Neitsch et al., 2005). A similar value (USLE $P=1$ ) was used by $L u$ et al., 2001 to find out erosion potential under no soil conservation practices over the Australian continent. Fifth, parameters affecting baseflow and groundwater recharge (GW_REVAP, REVAP_MN, and GWQMN) were modified so that their values should be in intermediate between the present condition (fully developed stage) and the extremely degraded poor stage (i.e. not suitable for agriculture). First, parameters ranges were identified for both the extreme boundary conditions. Groundwater parameters defined during model calibration represented the current developed stage, whereas, for the extremely degraded poor stage, parameter values are these: GW_REVAP $=0$, where movement of water from shallow aquifer and root zone does restricts, (ii) REVAP $\_$NN $=80$, a maximum limit beyond that parameter is found insensitive for revap or percolation to groundwater recharge; (iii) GWQMN = 0 , where substantial amount of infiltrated water reaches into river stream by return flow and very little amount left for groundwater recharge. Groundwater parameters for representing in situ practices are defined in Table III.

Representation of No ex situ management: SWAT requires details of time of construction of reservoirs at various locations and accordingly simulates reservoir induced effects on different hydrological components. We 

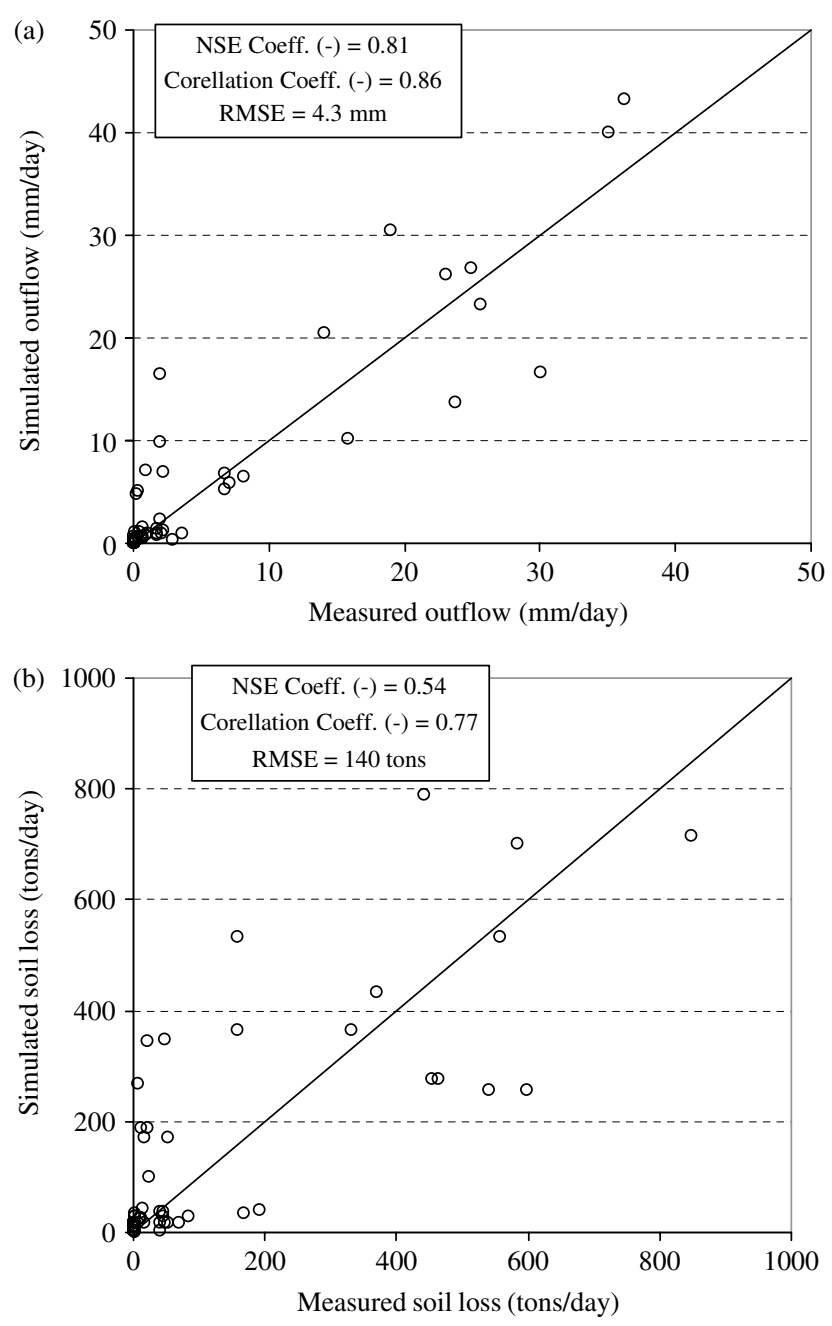

Figure 2. (a) Measured and simulated discharge at watershed outlet (reservoir No. 6) on daily time-step for $n=53$ events during 2002 and 2007. (b) Measured and simulated soil loss at watershed outlet (reservoir No.6) on daily time-step for $n=53$ events during 2002 and 2007

provided forthcoming dates of construction to eliminate ex situ management from the watershed.

\section{Model performance}

Amount of discharge and soil loss measured at watershed outlet is compared with simulated data on a daily time scale and shown by the scatter diagrams in Figure 2(a) and and (b), respectively. The performance of the model was assessed based on various statistical measures: correlation coefficient $(r)$, root mean square error (RMSE) and Nash-Suttcliffe efficiency (NSE) coefficient. The range of $r$ is 0 to 1 ; where 1 indicates perfect match. RMSE measures the average magnitude of the error in model prediction and varies from 0 to $\infty$. Simulation is considered good as it has minimum RMSE value. Positive values of NSE indicate that the calibrated model is a better predictor than the mean values of the observed discharge. The correlation coefficient $(r)$ was found to be 0.86 and 0.77 for discharge and sediment loss, respectively. $r$ values greater than 0.50 are generally considered 'satisfactory' and values greater than 0.70 are considered 'good' (Chiew et al., 2002) on daily time scale, hence, the model performance is considered acceptable. Similarly, NES coefficient for estimating flow and soil loss is found as 0.81 and 0.54 indicating good simulation capability, respectively.

A comparison of measured and simulated reservoir volume at four selected locations (larger reservoirs) is presented in Figure $3(\mathrm{a}-\mathrm{d})$. Dotted and smooth lines in the figure represent measured and simulated data, respectively, whereas, bars show total amounts of rainfall on daily time scale. Rapid rise in check dam volume immediately after a rainfall event suggests high inflow due to generated runoff from agriculture fields. Volume in the reservoir subsequently depleted as water gets percolated from the reservoir bottom and evaporates from the reservoir surface. The filling of a reservoir after rainfall events and its depletion is well captured at the beginning of the monsoon period (Figure 3). Some discrepancy was found particularly after September at a few locations. For example, simulated volume for reservoir-1 (Figure 3(a)) shows rapid declination compared to measured data between October and November months. Measured data suggests that the percolation rate in the beginning of the monsoon was relatively higher which might be due to the unsaturated state of subsurface layers. Moreover the percolation rate reduced after September due to increase in soil moisture content and water table rise (data not shown). Such temporal changes in hydraulic behaviour at the reservoir bottom could not be captured by SWAT. As a result, the model generated an extra void space in its simulation environment and consequently over captured runoff volume following rain events. The performance of the model was assessed by estimating correlation coefficient $(r)$ and RMSE as shown in Figure 3(a-d). Correlation coefficient $(r)$ and RMSE value at various locations were found to be in the range $0.72-0.87$ and $218-984 \mathrm{~m}^{3}$, respectively. These RMSE values are equivalent to maximum at $20 \%$ storage capacity of reservoir volume and, thus, the model performance is considered acceptable.

A comparison of measured and simulated cotton yield is shown in Figure 4(a) for 2005-2008. Results show that simulated yield is comparable to measured crop yield $(r=0 \cdot 87)$. Further, simulated groundwater storage was compared with measured groundwater table (average of different wells) on a monthly time scale and presented in Figure 4(b). These variables represent groundwater status but in different units and, therefore, each of the variables is shown as the primary and secondary $Y$ axis, respectively. Increasing trends of both variables shows groundwater recharge and decline (negative recharge) or utilisation during monsoon and post monsoon periods, respectively. Comparison shows that both the variables follow similar pattern, suggesting that the model is capable of estimating groundwater recharge appropriately.

\section{Validation}

Comparison with base-line/reference data: We validated results in various ways. Drainable porosity (also called the 'specific yield') of the groundwater aquifer 


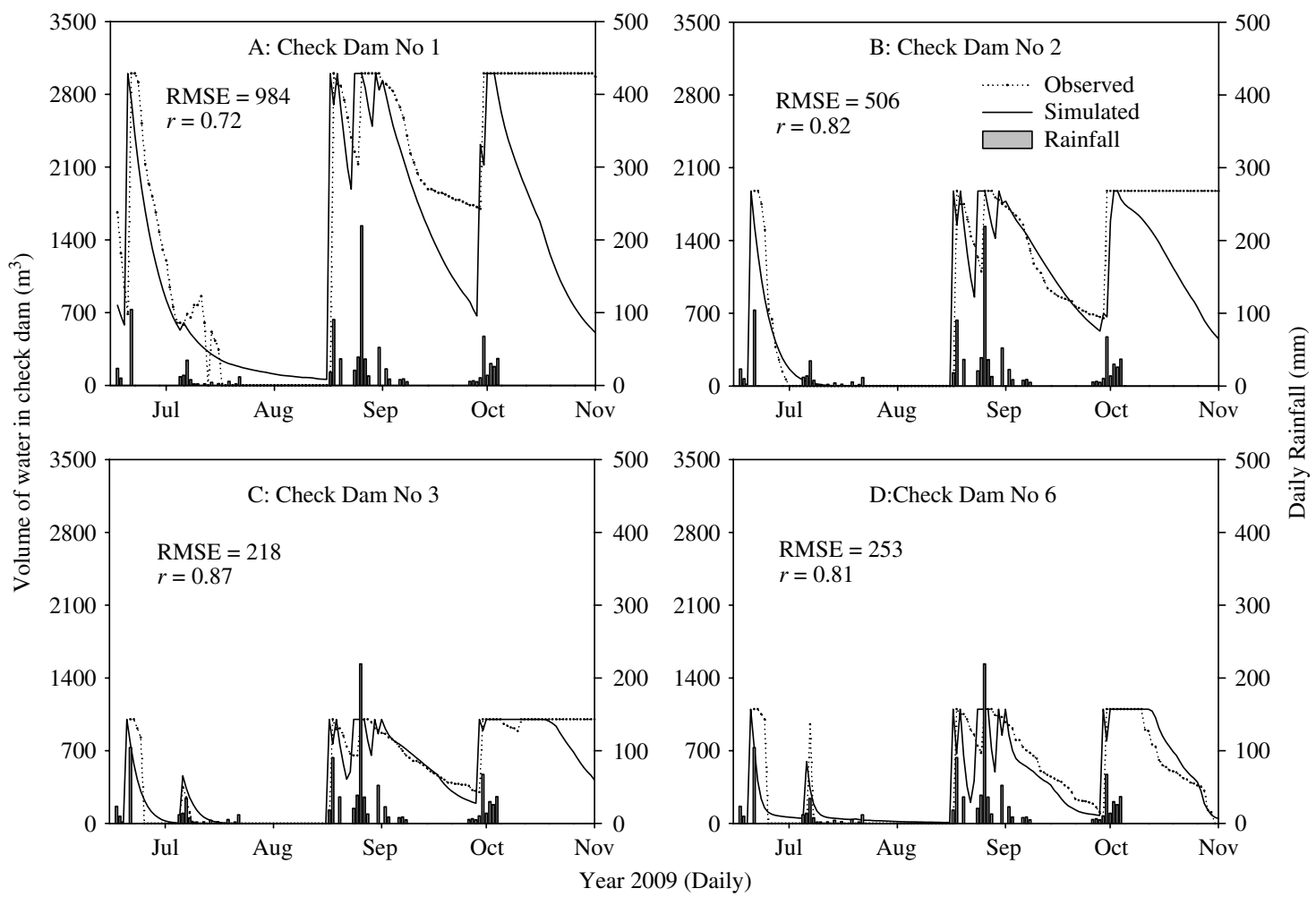

Figure 3. $(\mathrm{a}-\mathrm{d})$ : Measured and simulated volume in different storage structures during 2009
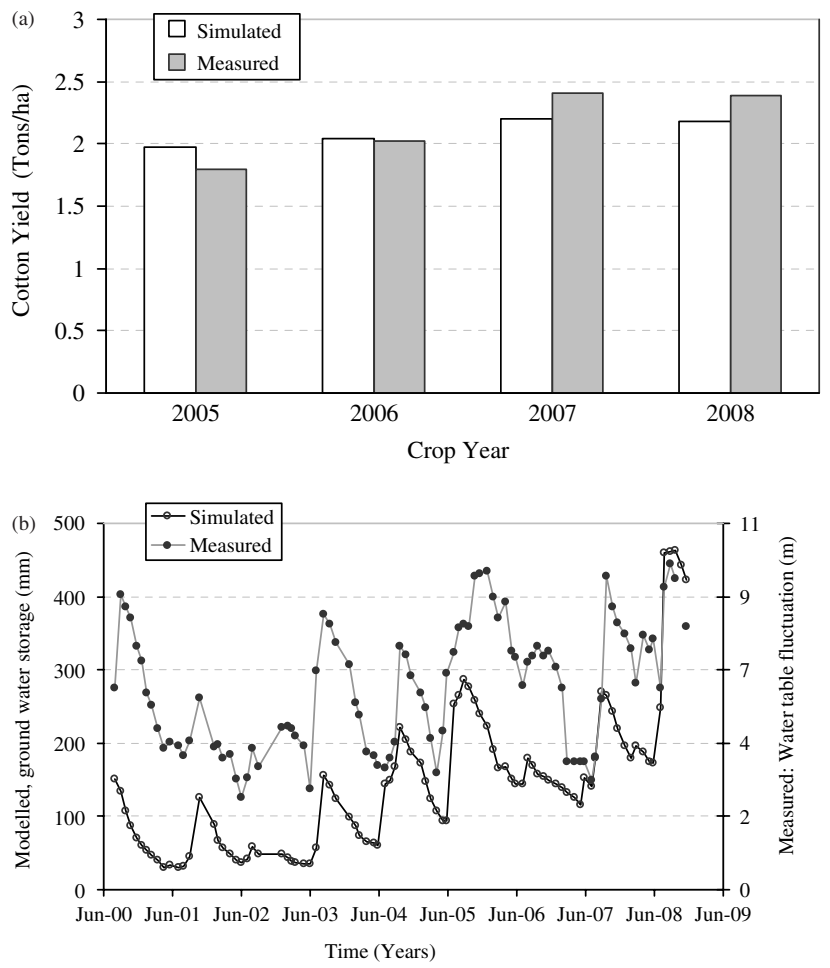

Figure 4. (a) Measured and simulated cotton yield during 2005-2008 in Kothapally watershed. (b) Comparison of measured data of groundwater table with simulated data of groundwater storage during 2000-2009 in Kothapally watershed

was estimated by using (1) difference in water table before and after the monsoon, and (2) simulated amount of groundwater recharge. We found the specific yield to be $3.1 \%$. Poor specific yield in this region is due to a hard rock (granite) aquifer. Similar results were also reported by Ahmed and Sreedevi, (2008) and Massuel et al., (2007) at larger scale in the Musi catchment (Table IV). The No Int. and Max Int. scenario represents pre-development (before 1999) and the current state of the Kothapally watershed, respectively. We calculated the change in groundwater availability (water table) and cropping intensity before and after watershed development from measured and simulated data and compared them (Table IV). Moreover, water productivity as estimated in the present study for the cotton crop was compared with other studies (Bastiaanssen et al., 1996; and Zwart and Bastiaanssen, 2004; Jalota et al., 2006) for similar rainfall regions. Crop water productivity is the amount of crop yield obtained per unit of water used (Toung and Bouman, 2003). We calculated water productivity from simulated ET and crop yield data. Table IV shows that modelled values are comparable with literature values (Bastiaanssen et al., 1996; Zwart and Bastiaanssen, 2004; Jalota et al., 2006).

Inflow at Osman Sagar reservoir: The results from the Kothapally watershed were scaled up to represent the whole catchment area $\left(750 \mathrm{~km}^{2}\right)$ of the Osman Sagar reservoir, and simulated inflows to the dam were then compared with actual inflows for validation purpose. Land use information for the Osman Sagar catchment shows that 21,35 , and $19 \%$ of total geographical area of catchment is under agriculture, fallow land, and waste land category, respectively (Census data, 2001, Government of Andhra Pradesh, India). Fallow and waste lands remain uncultivated and were being used for grazing. 
Table IV. Model validation

\begin{tabular}{|c|c|c|c|}
\hline Parameter & $\begin{array}{l}\text { Modelled values in } \\
\text { present study }\end{array}$ & $\begin{array}{c}\text { Measured/literature } \\
\text { values }\end{array}$ & Validation source \\
\hline \multicolumn{4}{|l|}{ Current stage of Kothapally } \\
\hline \multirow[t]{2}{*}{$\begin{array}{l}\text { Specific yield or drainage } \\
\text { porosity }(\%)\end{array}$} & $3 \cdot 1$ & $2 \cdot 4$ & $\begin{array}{l}\text { Massuel et al., 2007; Ahmed } \\
\quad \text { and Sreedevi, 2008 }\end{array}$ \\
\hline & & $4 \cdot 5$ & Pathak et al., 2002 \\
\hline \multirow{2}{*}{$\begin{array}{l}\text { Cotton water productivity } \\
\qquad\left(\mathrm{Kg} \mathrm{m}^{-3}\right)\end{array}$} & $0 \cdot 38-0 \cdot 45$ & $0 \cdot 27-0 \cdot 31$ & Jalota et al., 2006 \\
\hline & & $\begin{array}{c}0.46 \\
0.41-0 \cdot 95\end{array}$ & $\begin{array}{l}\text { Bastiaanssen et al., } 1996 \\
\text { Zwart and Bastiaanssen, } 2004\end{array}$ \\
\hline \multicolumn{4}{|c|}{ Changes made from pre-development (before 1999) to post-development (present stage) period } \\
\hline $\begin{array}{l}\text { Average rise in } \\
\text { groundwater table }(\mathrm{m})\end{array}$ & $3.1 \mathrm{~m}$ & $2.5 \mathrm{~m}$ & Measured data \\
\hline $\begin{array}{l}\text { Potential increase in } \\
\text { irrigated area during } \\
\text { post monsoon crop } \\
\text { season ( } \% \text { of watershed } \\
\text { area) }\end{array}$ & $13-31 \%$ & $10-30 \%$ & Surveyed \\
\hline
\end{tabular}

Agricultural land (80-90\% of total area) in Kothapally was mostly under rainfed conditions before 1999. As Kothapally is part of the Osman Sagar catchment; topographical features (vary from 0.20 to $0.50 \%$ ) and soils are similar. Both Kothapally watershed and Osman Sagar catchment were dominated by degraded land areas prior to 2000 when the watershed management interventions started.

Thus, the inflow at Osman Sagar is calculated by using the same annual rainfall-runoff relationship as was simulated for the Kothapally watershed, by multiplying the outflow from the catchment by a factor of 256 (area of Osman Sagar catchment/area of Kothapally watershed) to estimate the inflow into the Osman Sagar reservoir under the No Int. scenario. These estimates were compared with measured inflows from 1984 to 1999 on a monthly and yearly time scale which is presented in Figure 5(a) and (b), respectively. Simulated inflows match quite well with measured data both for dry and wet years on both monthly (correlation coefficient $=0.86 ; \mathrm{RMSE}=20 \cdot 3 \mathrm{MCM}$; NSE Coefficient $=0.86$ ) and yearly time scale (correlation coefficient $=0.86$; RMSE $=28$ MCM; NSE Coefficient $=0.70$ ). More specifically, results compared for yearly time scales show that simulated flow is found to be better for the initial period (1984-1994) than the later period (1995-1999) as simulated data is found to be overestimated after 1994. Village-level demographic data from the Osman Sagar catchment area (collected from Government of Andhra Pradesh, India) shows that various kinds of watershed development activities (constructions of check dams, gully control structures, etc.) have been implemented in various phases after 1994 under the national watershed development program in Osman Sagar catchment area. This result supports the creditability of modelled parameters for representing no in situ land practice in model setup during scenario development.

\section{RESULTS}

Water balance components of different agricultural water management intervention scenarios

Different soil and water conservation interventions significantly changed the water balance components in the watershed. Results are presented for dry, normal, and wet years according to the following classification (Indian Meteorological Department, Pune, India, http://www.imdpune.gov.in): rainfall less than $25 \%$ of the long-term average $=$ dry; rainfall between $-25 \%$ and $+25 \%$ of the long-term average $=$ normal; rainfall greater than $25 \%$ of long -erm average $=$ wet. Total number of dry, normal, and wet years in the 31-year period was found as 8, 16, and 7 times, respectively.

The water balance is affected by management interventions (Figure 6). For the degraded state (No Int.), approximately $64 \%$ of the rainfall was partitioned into ET, whilst approximately $9 \%(70 \mathrm{~mm})$ recharged the groundwater aquifer and 19\% $(151 \mathrm{~mm})$ was lost from the watershed boundary as outflows during the cropping season. When the watershed development programme was in place (Max Int.) the amount of water partitioned as ET had increased to around $576 \mathrm{~mm}$, equivalent to $72 \%$ of annual average rainfall. Groundwater recharge was also higher $(174 \mathrm{~mm})$, while outflow from the watershed was less than $10 \%$ of the total water balance, i.e. $70 \mathrm{~mm}$ or less than half of what it was before the interventions. Constructing check dams (ex situ) substantially increased groundwater recharge (ex situ), while reducing outflows. In situ practices resulted in a higher ET, since more water was available as soil moisture in the fields, higher groundwater recharge and lower outflow.

The water partitioning differs significantly between dry, normal and wet years (Figure 6). A large fraction of the total rainfall amount $(85-90 \%)$ is converted into evapotranspiration (ET), while only a fraction generated outflow and groundwater recharge in dry years. On the other hand, only about $50-60 \%$ of the total rainfall was 

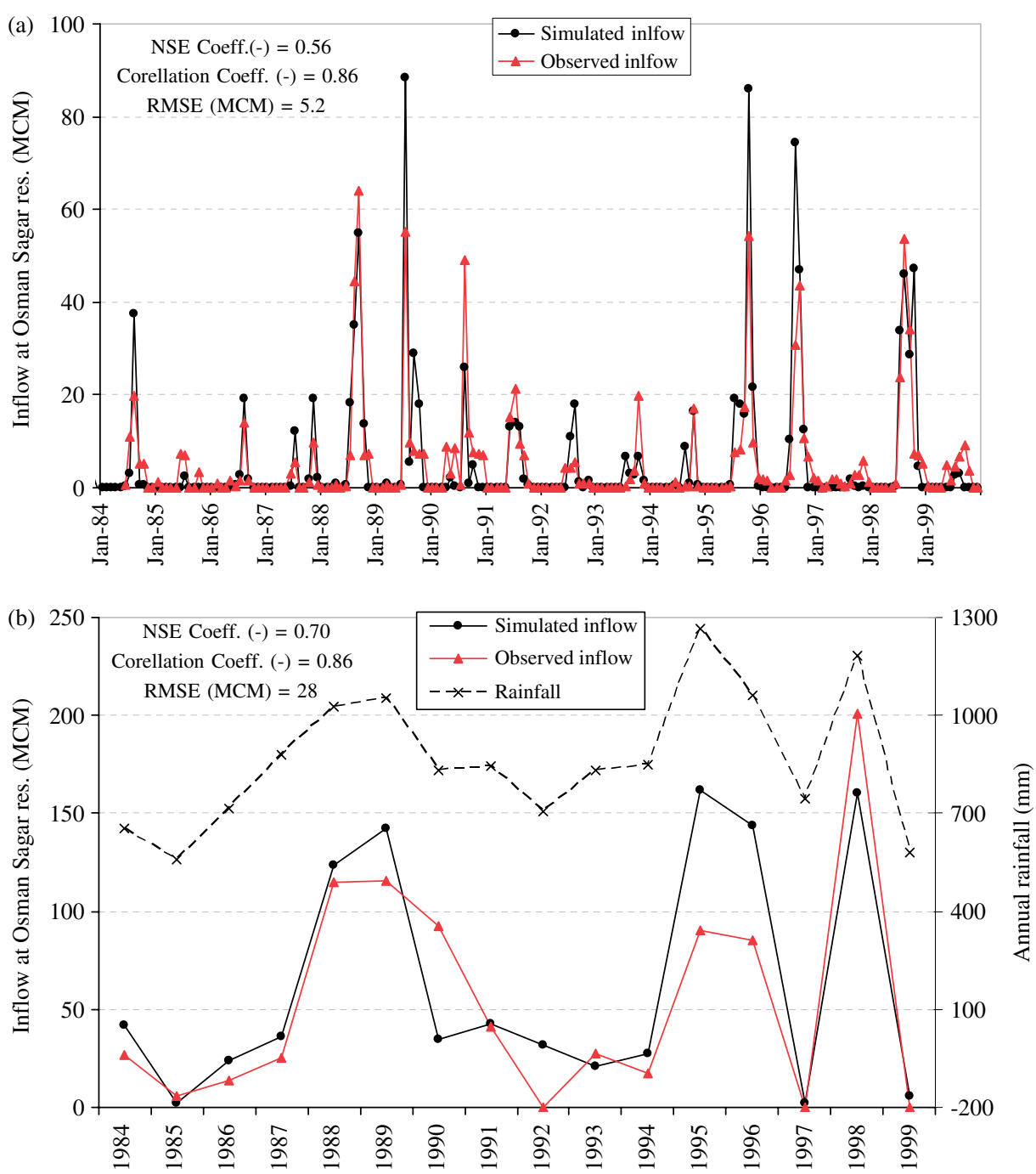

Figure 5. (a) Measured and upscaled inflow at Osman Sagar reservoir for 1984-1999 at monthly time step. (b) Measured and simulated inflow at Osman Sagar reservoir for 1984-1999 at annual time step

converted into ET during wet years. In the degraded state of the watershed, represented by the No Int. scenario, outflow is small $(<5-8 \%$ of the total rainfall $)$ in dry years, but with water interventions in place, outflow is almost negligible. During normal and wet years, outflow is reduced by $30-60 \%$ with water interventions compared with the degraded state.

Groundwater recharge varies between 50 and $300 \mathrm{~mm}$ for dry and wet years, respectively (Figure 7(a)). Thus, the variation in groundwater recharge is larger between years than between treatments. During dry years, water management interventions became particularly important for groundwater recharge, which was more than twice as high for both ex situ and in situ interventions compared with the degraded state. Groundwater availability impacts the potential to grow a second, fully irrigated crop during the dry season (Figure 7(b)). Again, the variation between years is larger than between treatments. The irrigation potential is more than doubled with water management interventions during dry and normal years.

In situ water management resulted in higher soil moisture availability (Figure 7(c)). This pattern was same for dry, normal, and wet years. Ex situ water management had a small impact on soil moisture availability for all years, since the result is for the rainy cropping season only.

Outflow varies significantly between years and with water management interventions (Figure 7(d)). Outflow was more than ten times higher during wet years compared with dry years. With water maximum management interventions, outflow from the watershed was more than halved compared to the degraded state. A linear relationship was found between rainfall amount and outflow of water from the watershed on a yearly time scale (Figure 8), but varied with water management interventions on the field scale. The lowest outflow was generated with both check dams and in situ water management in place (Max Int.), while the No Int. generated the highest outflow, per rainfall event. Moreover, the results show that runoff losses were smaller for in situ management (In situ) compared to ex situ interventions (Ex situ), indicating that practicing in situ management caused larger outflow reductions from the fields than check-dams in this case. 


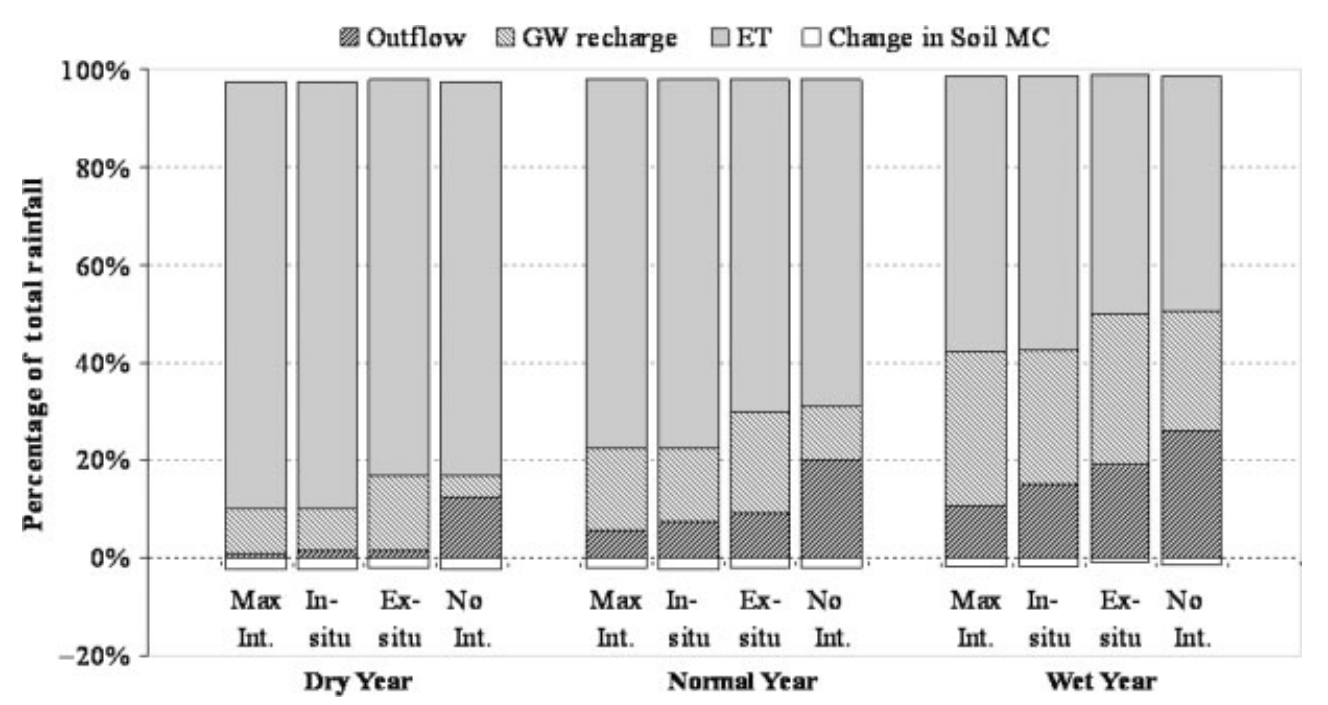

Figure 6. Water balance for the four different water management scenarios for the first cropping season (from June to Dec) of different water years: dry $(n=8)$, normal $(n=16)$ and wet years $(n=7)$ years (data from 1978 to 2008). Max Int.: In situ + check dams; In situ: In situ + No check dams; ex situ: No in situ + check dams; No Int.: No in situ + No check dams. GW recharge $=$ groundwater recharge. ET $=$ evapotranspiration.

Change in SMC $=$ Change in soil moisture content
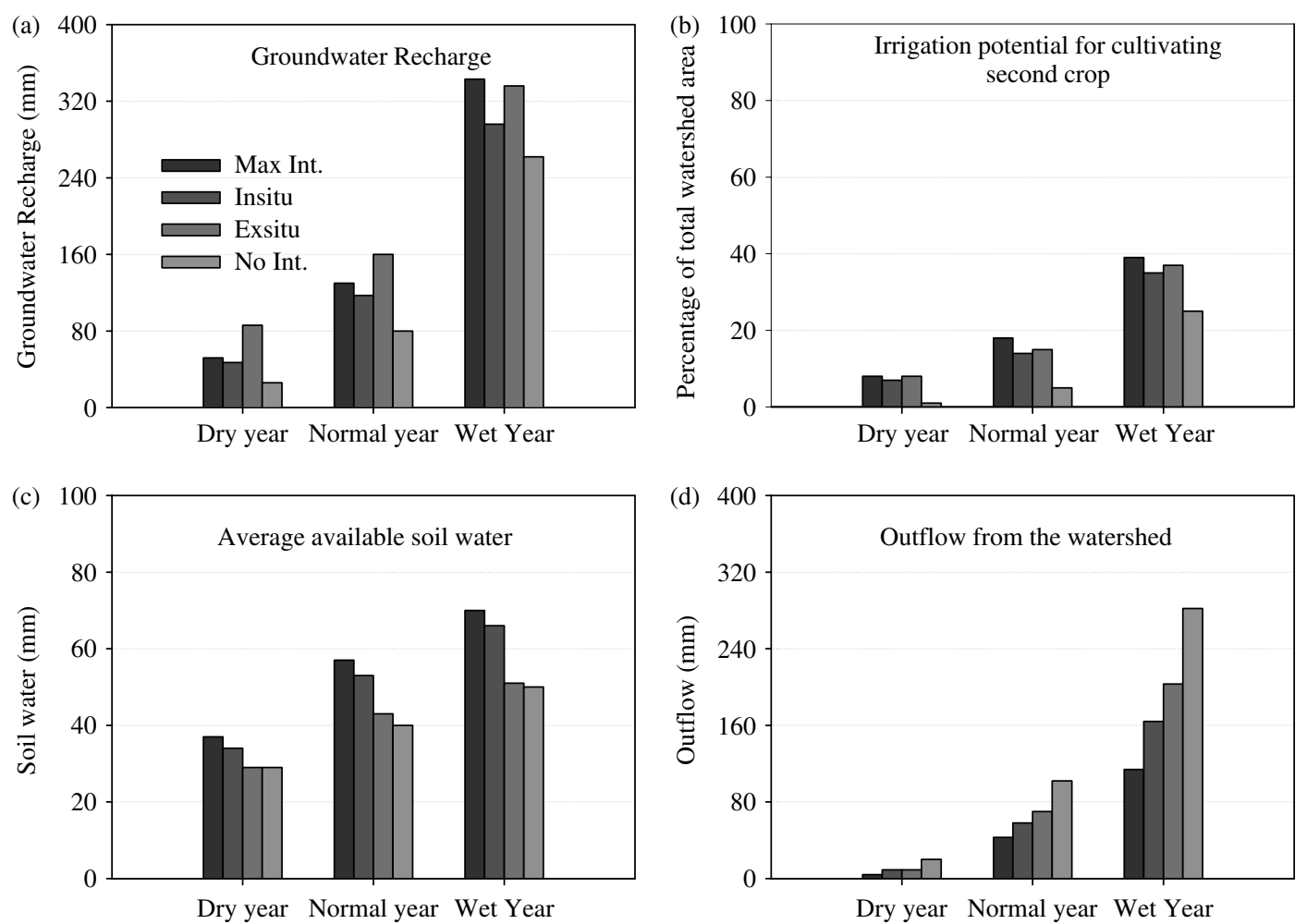

Figure 7. Comparison of groundwater recharge (a), developed irrigation potential (b), average available soil water during crop period (c), and outflow amount in different land management scenarios (d) during dry $(n=8)$, normal $(n=16)$ and wet years $(n=7)($ data from 1978 to 2008$)$

\section{Monthly water balance}

To show a detail description of mass balance, the monthly water balance of Kothapally watershed is presented for one year (June 2003 to May 2004), which is a normal year in terms of total rainfall, for the maximum interventions scenario (Figure 9). About $80 \%$ of the rainfall $(689 \mathrm{~mm})$ occurred during June-October, ET was generally large during the cropping season, groundwater recharge occurred predominantly in July and August, and outflow was measured only in August. The rainfall that occurred in June and July was captured completely by the watershed by increasing the soil moisture content and recharging the groundwater aquifer. Once the soil and water storage compartments were filled the rainfall was sufficient to generate a surplus flow from the watershed boundary which occurred in August. Rainfall during the non-monsoon period was small. A second post-monsoon crop was grown on $30 \%$ of the land area of the watershed where irrigation facilities are available. Thus, for this crop, groundwater was the main source of water, 


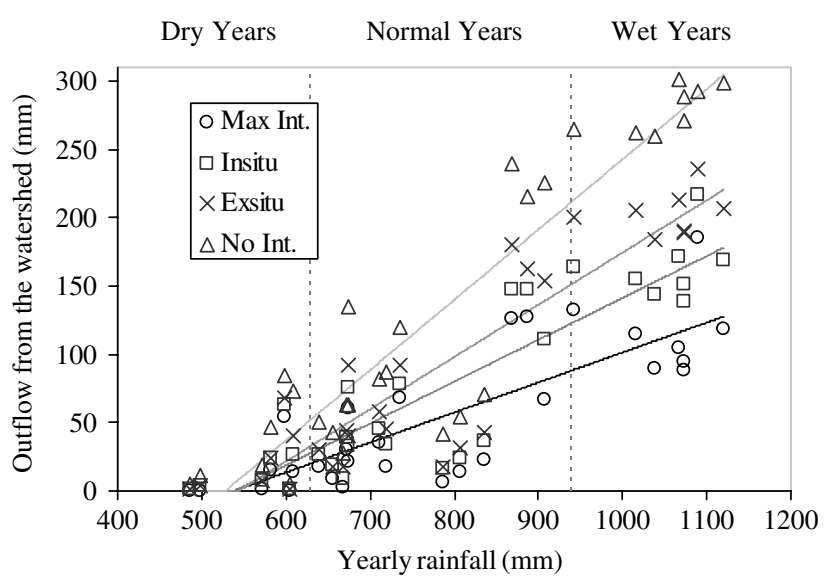

Figure 8. Rainfall-runoff relationship for the four different water management scenarios. Results based on 31 years of simulation run from 1978 to 2008. Max Int.: in situ + check dams; in situ: in situ + No checkdams; ex situ: No in situ + check dams; No Int.: No in situ + No check dams

as depicted in Figure 9 as an increase in soil moisture content.

\section{Impact of water interventions on crop yield}

Comparison of crop yield among different water intervention scenarios are shown for dry, normal and wet years (Figure 10). This figure shows that approximately $15-35 \%$ improvement was found in crop yield by various water interventions compared to No Int. conditions. Some limited irrigation was provided in the crop area after the monsoon period, otherwise this difference would have been much larger between watershed intervention and No Int. scenarios.

\section{Sediment transport and soil loss}

The average soil loss from the watershed was less than 3.0 ton $\mathrm{ha}^{-1}$ in all years except in year 2000, when Kothapally experienced a heavy downpour of $303 \mathrm{~mm}$ within $24 \mathrm{~h}$ in August, which created enormous amounts

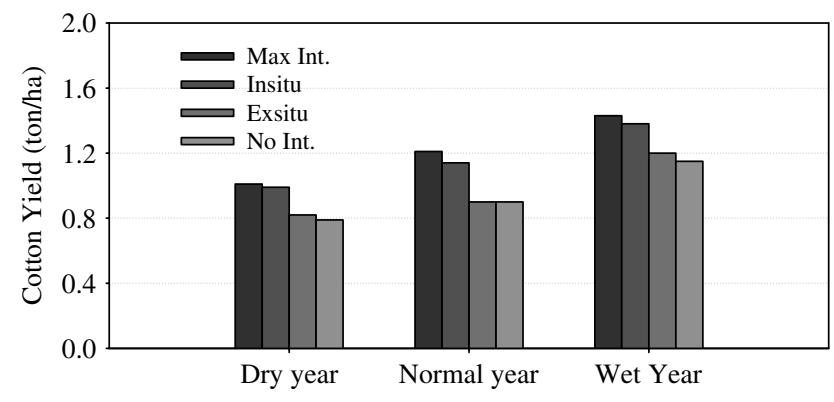

Figure 10. Comparison of cotton yield in different land management conditions during dry $(n=8)$, normal $(n=16)$ and wet years $(n=7)$ (data from 1978 to 2008)

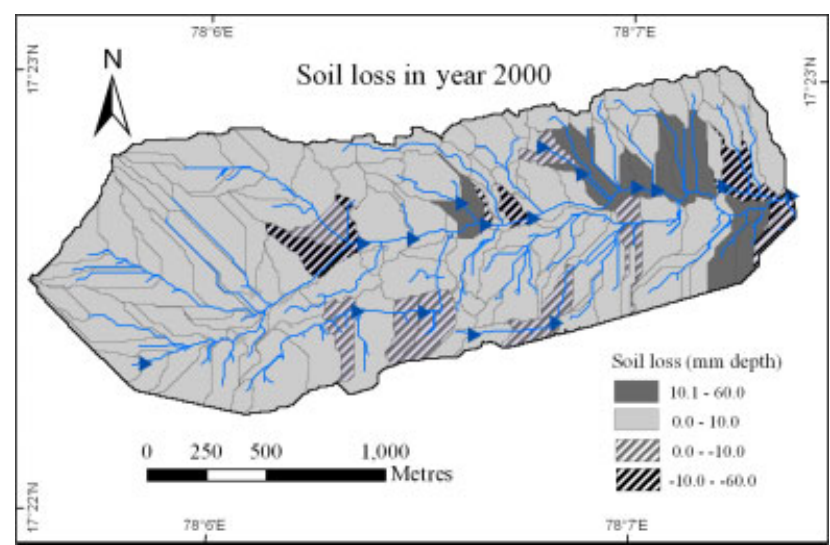

Figure 11. Soil loss in different sub-units of Kothapally village in 2000. Gray colour in map shows soil loss and crossed lines shows its deposition (also shown by negative numbers)

of runoff and soil loss from the watershed boundary. Simulations suggest that, on average, $7 \mathrm{~mm}$ of soil was lost from the entire watershed due to this extreme event. A soil loss map for year 2000 shows that soil was lost from a large area of the watershed (Figure 11). The detached soils were deposited in those sub-units where a check dam was built, since the check dams reduced the

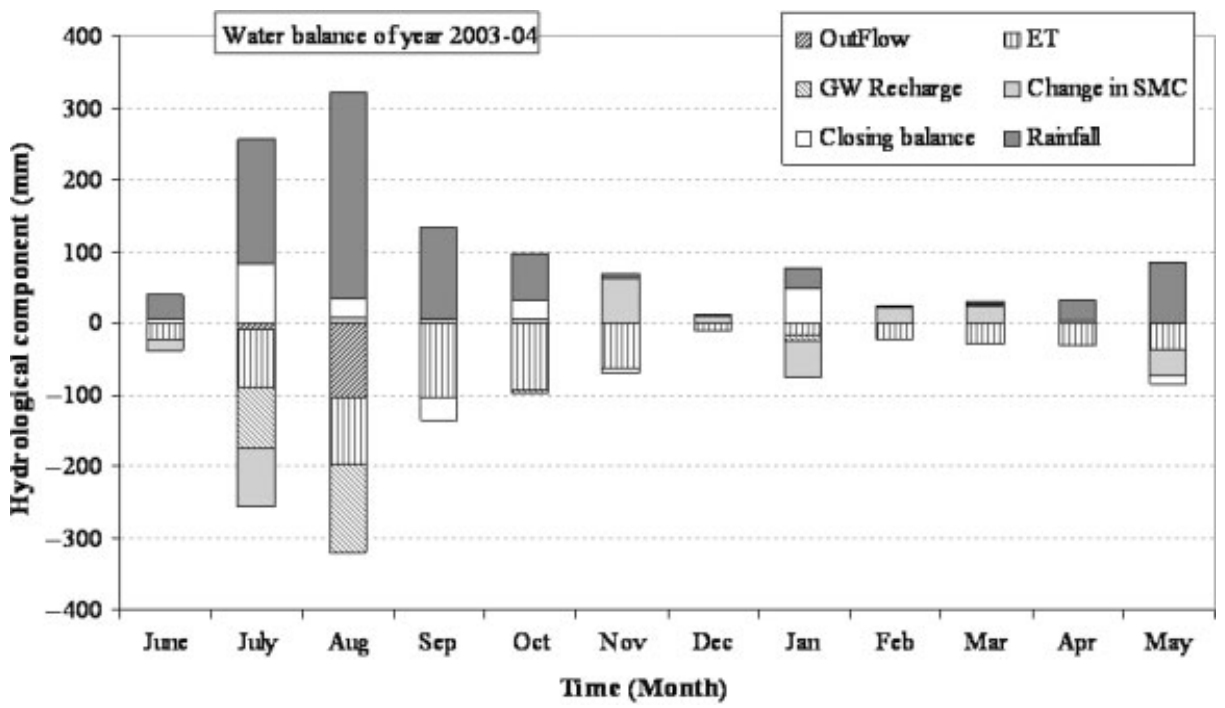

Figure 9. Monthly water balances for 2003-2004 for the Kothapally watershed management programme. The upper part of the graphs shows the source of the water, and the lower part presents various sink components: ET, groundwater recharge, change in soil moisture content, and outflow from the watershed 

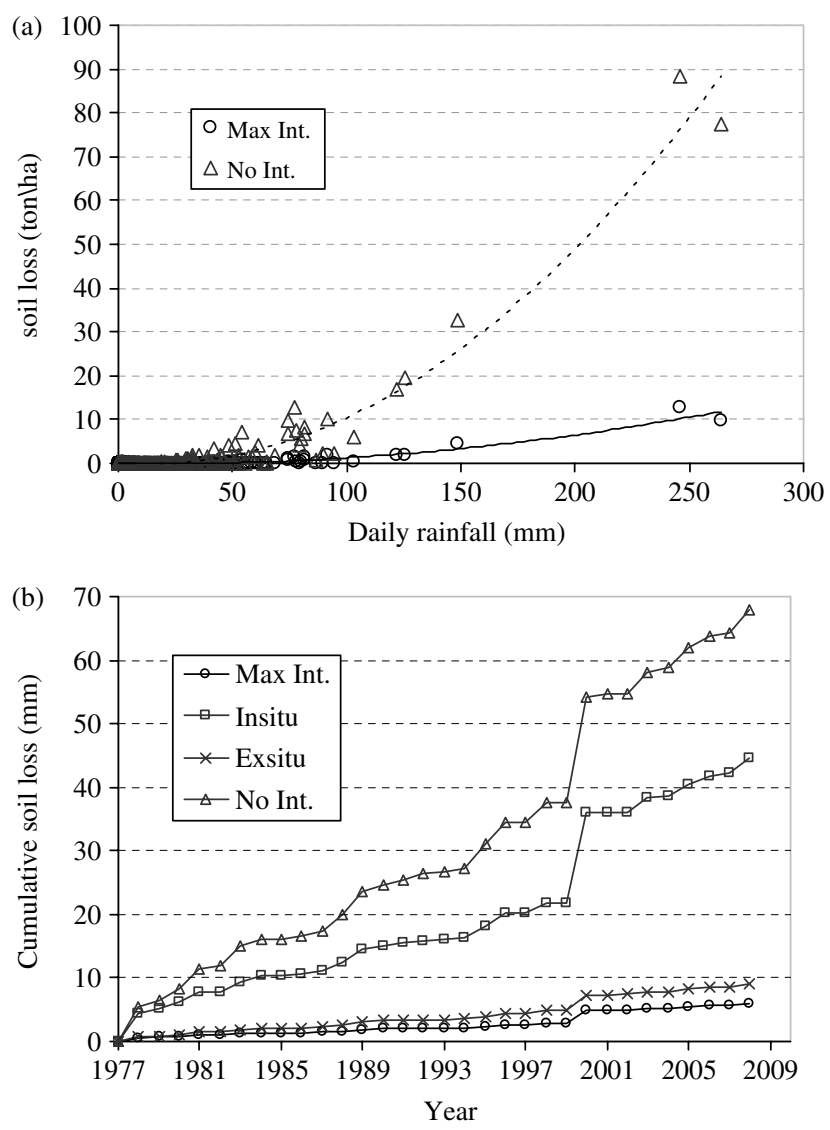

Figure 12. (a) Rainfall versus soil loss, and (b) Cumulative soil loss for different management scenarios. Max Int.: in -situ + check dams; in situ: in situ + No check dams; ex situ: No in situ + check dams; No Int.: No in situ + No check dams

flow velocity of the water and allowed silt particles to settle down.

Soil loss was strongly affected by rainfall intensity (Figure 12(a)). Rainfall intensities below 20-30 mm/day did not generate much soil loss in any of the four intervention scenarios. However, a clear difference in soil loss was observed between the maximum interventions scenario and the No Int. scenario. At rainfall intensities above $50 \mathrm{~mm} /$ day, 5-8 times more soil was lost from the system for the scenario without agricultural water management interventions compared to maximum interventions. On average, $2-3$ events with rainfall intensities greater than $50 \mathrm{~mm}$ day $^{-1}$ generally occurred every monsoon season in the Kothapally watershed, and once every three years the area experienced rainfall intensities above $100 \mathrm{~mm} \mathrm{day}^{-1}$, creating situations with heavy soil losses without water management interventions in place.

Cumulative soil loss generated from the watershed outlet from the various water management scenarios is presented in Figure 12(b) for the 31-year simulation period. There were marked differences in sediment reduction due for scenarios with ex situ interventions (Ex Situ and Max Int.) compared to in situ or No Int. scenario (In situ and No Int.). The average soil loss from the watershed in different land management scenarios was 2.5, 4.0, 15, and 22 tons/ha/year for Max Int., Ex situ, In situ, and No Int. scenarios, respectively.

\section{DISCUSSION}

Water management interventions improved the resilience of small-scale tropical agricultural systems

Because of the watershed development programmes, the livelihoods of the farmers in the Kothapally village have improved (Sreedevi et al., 2004; Wani et al., 2006). Agricultural yields are on the increase, and farmers are now able to save some of the income generated by the farm and to reinvest in their business. Because of diversification of sources of income due to more offfarm activities, their resilience to external shocks has improved. More specifically, the water interventions have reduced the inherent risks in agriculture in the semi-arid zone posed by high rainfall variability and frequent dry spells, thereby strengthening the resilience to drought in tropical agriculture. With more erratic rainfall under future climate change, water management interventions in tropical agriculture are likely to be of even greater importance.

Watershed management programmes including in situ water harvesting and check dams significantly changed the water resource availability in the watershed (Shiferaw and Rao, 2006; Shiferaw et al., 2009). In situ water management practices improved infiltration capacity and the water holding capacity of the soil, which resulted in higher crop water availability. This was particularly important during dry years when yields were low. The construction of check dams (ex situ structures) led to higher groundwater recharge, which enabled improved supplementary irrigation of the monsoon crop (in this case cotton). With higher groundwater levels the areas used to grow a second, fully irrigated cash crop (normally vegetables) during the dry season could be expanded, which makes an important financial contribution to the household budget. The ex situ systems also captured a large fraction of the sediments lost from the fields, which the farmers carried back again during the dry season.

Sreedevi et al., 2004; Wani et al., 2006 reported that water availability and crop yield have substantially improved after the watershed development program was implemented in Kothapally watershed. Since 1999, several shallow wells that had low groundwater levels have reverted to active wells for irrigation. The cropping pattern has changed in recent years as a consequence of improved soil moisture availability and irrigation access. Farmers who used to be cultivating cotton of traditional varieties, sorghum, maize, paddy, onion, and chilies before the onset of the watershed development programme, have switched to cultivating higher yielding cotton varieties (BT cotton). Maize and paddy are now cultivated only in limited areas during the monsoon, and vegetables are being grown in the irrigated area during the summer. Along with in situ and ex situ agricultural water management interventions, farmers have also adopted better nutrient and pest management as well as more timely operations (Sreedevi et al, 2004), which further improves agricultural productivity.

High rainfall intensities are expected to become more frequent in the future as the climate is predicted to 
become more extreme (IPCC, 2007). Soil loss increases exponentially with rainfall intensity (Figure 12(a)). This results in a loss of fertile soil from the agricultural land, as well as sedimentation of the river systems and the reservoir downstream. In particular, the ex situ structures result in significantly less soil loss from the watershed (Figure 12(b)). Moreover, high rainfall intensities may cause flooding of downstream systems, which may partly be counteracted by the better soil and water management practices carried out within the watershed development programmes. Thus, these interventions might become even more important in the future to combat the effects of high rainfall intensities.

The choice of water management intervention depends on hydro-ecological and social settings

The strategy of the watershed development program should be based on hydro-ecological zones and soil characteristics. In situ management may be sufficient at higher rainfall amounts, while ex situ water management for supplementary irrigation may be needed to complement the in situ system at lower rainfall amounts (below $600 \mathrm{~mm} / \mathrm{yr}$ ) and to bridge dry spells. However, practicing both in situ and ex situ management in low rainfall zones may not be economically viable because with in situ management there may not be enough local runoff to collect in the ex situ storage systems. At rainfall amounts above $600 \mathrm{~mm} / \mathrm{yr}$, both practices might be implemented without the risk of them competing with each other for water. In situ practices in such areas would improve infiltration and at the same time check dams can store surplus amounts of water and sediment. A common strategy cannot be implemented everywhere: it depends on topographic and soil characteristics, the location of the watershed and the objective of the development (Joshi et al., 2005, 2009).

Ex situ management is helpful for storing water but it may create an unequal distribution if only some of the framers will benefit. In the Kothapally village, some farmers have wells on their properties which they use for irrigation of their own fields first, and, if there is water left after they have fulfilled their own irrigation requirements, they allow neighbouring farmers to use their water for a proportion of the income from that farm. Thus, in the Kothapally case, the farmers with wells on their properties will benefit more through having check dams than the others.

\section{Balancing water needs between upstream and downstream systems}

Implementing agricultural watershed interventions, such as in situ and ex situ water-harvesting systems on a large scale can improve green water use efficiency and groundwater recharge at onsite locations; and consequently, have a positive impact on crops, water productivity, and livelihood of small and marginal farmers in rain-fed areas upstream. On the other hand, such interventions may cause reductions in water availability downstream. The outflow from the Kothapally watershed was reduced by more than $50 \%$ after the implementation of the watershed development programme. Thus, if the current agricultural management practices were changed into watershed development programme interventions on all agricultural land in the Osman Sagar catchment, the inflow to the reservoir downstream could potentially be halved. On the other hand, sediment loads to the river simulated at the outlet of the Kothapally watershed after the implementation of the watershed programme was less than one-tenth of what it was before. Such large reductions of sediment loads to the rivers are likely to have a large positive impact on the in-stream river ecology and the lifespan of reservoirs.

Downstream negative impacts may be aggravated under a more extreme and drier climate. During dry years, hardly any outflows were generated from the Kothapally watershed during the monsoon cropping season, and since most of the rain falls during this period, almost no water from this site reached the reservoir. Thus, from that perspective, watershed development programmes may be crucial to build resilience in upstream locations, while adversely affecting downstream systems. On the other hand, higher rainfall intensities may cause large runoff amounts over a short period of time, which certainly would create flood situations at downstream locations. Moreover, heavy soil loss from the field is expected at high rainfall events, causing large sediment loads to downstream systems and also degradation of lands in upstream areas. In both these latter cases, water management programmes would reduce the negative impact on the downstream systems resulting from high rainfall intensities.

It is therefore not evident whether watershed management programmes will have an overall positive or negative impact on downstream systems, and region-specific analysis is needed to assess trade-offs for downstream areas along with onsite impact. Stakeholders' interests in both upstream and downstream locations have to be considered and weighed together, and impacts from different interventions need to be clearly illustrated in different scenarios so that potential trade-offs can be understood by all stakeholders. These scenarios have to take climate change impacts into account, and encompass all the ecosystem services provided by water in the system, as well as the risk of systems crossing a threshold that puts them in an undesired state.

\section{Comparison of results with other studies}

A review of natural resource management in semiarid tropics made by Sahrawat et al., 2010 concluded that integrated use of soil and water conservation practices with provision of balanced plant nutrients can not only sustain increased productivity but also maintain soil quality in watershed or catchment level. Similar to Kothapally, other benchmark studies of ICRISAT in India and Thailand also showed $50-70 \%$ reduction in surface runoff, considerable reduction in soil erosion and remarkable improvement in crop productivity after land and water interventions compared to previous conditions (Wani et al., 2007). Shemdoe, et al., 2009 reported 
increase in crop yield in semi-arid areas of Tanzania by mulching their fields using locally available material, in situ practices, and improved tillage.

\section{Uncertainties in the analysis}

Modelling natural systems is a challenging task. Natural systems are highly complex, heterogeneous, and nonlinear in nature. Ecohydrological modelling includes various assumptions, error in input and measured data, and limitation to capture complete physical process of system; which turns up uncertainty in simulation outputs. We have listed some of the assumptions made in the present study and model limitations. We assumed one kind of land use practice throughout the simulation period in the entire Kothapally watershed area to simplify the process, which may generate some discrepancy, particularly at micro scale or at shorter time interval (daily or monthly). Data availability and its quality strengthen the calibration process. In the present study, volume-stage data of various reservoirs is available for a one-year period. The model was calibrated with available data, but some important events are missing. For example, gauge and sediment data is not available at one extreme event in the year 2000, and the model may therefore simulate biased results for such rainfall events. An attempt was made to characterize soil physical properties and to capture minor structural details, but uncertainties remain due to landscape heterogeneity. For example, soil hydraulic conductivity estimated from basic textural data shows a wide parameter range with in watershed boundary (Table I).

SWAT is a semi-process-based model and, therefore, it has limited capacity to capture physical processes and their temporal dynamics completely. For example, we found variable hydraulic behaviour of the reservoir bottom at the stream channel, but SWAT does not capture such variability, which results in errors in the simulation. Moreover, SWAT assumes unlimited water storage capacity of the groundwater aquifer system, which is impractical, particularly for hard rock areas, which usually have poor specific yield and limited storage space. All kinds of in situ management (e.g. contour bunds, graded bunds, field bunds, terraces formations, etc.) in the model setup are parameterized by the same variables, although the purpose of building these structures is different: some land practices disposes runoff water safely from the field boundary (graded bunds) and some of them completely entrap water into the field itself (like contour bunds and field bunds). Therefore, the impact of such interventions could not be identified individually and the model produces results in an aggregate way rather than focusing on one factor.

\section{CONCLUSIONS}

Watershed interventions in agriculture in the forms of in situ and ex situ water harvesting systems are important for strengthening the resilience to drought in tropical agriculture in uplands which are hot-spots of poverty, water scarcity, and land degradation. Both practices resulted in higher groundwater recharge from 9 to $20 \%$ of total rainfall, which enabled supplementary irrigation of the monsoon crop to bridge dry spells and full irrigation of a second dry season crop on $30 \%$ of the fields, on average. Moreover, in situ water interventions led to 10-30\% higher soil moisture availability in the fields, resulting in enhanced green water use efficiency which is very critical. The inter-annual variation in the results is large: the interventions were found to be most important during dry years when groundwater recharge and ET were low without interventions. At the same time, agricultural water interventions may cause trade-offs in terms of reduced water flows by $30-60 \%$ to downstream systems. The outflow from the Kothapally watershed was more than halved after the implementation of the watershed management programme. On the other hand, soil loss decreased by a factor of ten because of the watershed development programme, which is expected to have positive impacts on in-stream river ecology and runoff generation for other downstream water uses.

Under a new climate with lower slightly reduced annual average rainfall amounts and higher rainfall intensities, interventions such as those implemented under the watershed development programmes in India may be increasingly important for securing agricultural yields in upstream areas to achieve food security and improve livelihoods of small and marginal farmers through increase in green water use efficiency. However, on the other hand, that may result in reduced water flows to downstream systems. High rainfall intensities may cause flooding and large sediment loads to downstream systems, which may partly be counteracted by better soil and water management practices carried out within the watershed development programmes. The conclusion is that it is important to clearly illustrate impacts and trade-offs in both upstream and downstream locations for different agricultural water interventions, accounting for changes in climate, water-related ecosystem services and the risk of ecosystems crossing thresholds into an undesirable state as well as the important goal of achieving sustainable development and reducing poverty in the developing tropical regions.

\section{ACKNOWLEDGEMENTS}

This research was supported by a research grant from the Swedish International Development Cooperation Agency (SIDA) during year 2009. The authors would like to thank the team of Research Program1-Resilient DryLand Systems, ICRISAT, for collecting and providing historical research data and their support. The authors are grateful to Dr P. Pathak, Scientist, ICRISAT for providing water and sediment flow data of Kothapally watershed, and to Irrigation and Command Area Development, Hyderabad for providing Osman Sagar inflow data on monthly time scale. The authors are grateful to consortium partners, Central Research Institute for Dry land 
Agriculture (CRIDA); National Remote Sensing Centre (NRSC); District Water Management Agency (DWMA), Hyderabad, Andhra Pradesh; Non-Government Organizations (NGOs) and Watershed Committee for implementing watershed development program in Kothapally watershed. The authors are also grateful to funding agencies, Asian Development Bank, Government of Andhra Pradesh and Government of India for providing development funds for Kothapally watershed.

\section{REFERENCES}

Abbaspour KC, Yang J, Maximov I, Siber R, Bogner K, Mieleitner J, Zobrist J, Srinivasan R. 2007. Modelling hydrology and water quality in the pre-alpine/alpine Thur watershed using SWAT. Journal of Hydrology 333: 413-430.

Ahmed S, Sreedevi PD. 2008. Simulation of flow in weathered-fractured aquifer in a Semi-Arid and over-exploited region. In Groundwater dynamics in hard rock aquifers, Ahmed S, Jayakumar R, Salih A (eds), Springer Publication

Arabi M, Frankenberger JR, Engel BA, Arnold JG. 2008. Representation of agricultural conservation practices with SWAT. Hydrological Processes 22: 3042-3055.

Arabi M, Rao SG, Mohamed MH. 2007. Probabilistic approach for analysis of uncertainty in the evaluation of watershed management practices. Journal of Hydrology 333: 459-471.

Arnold JG, Allen PM. 1996. Estimating hydrologic budgets for three Illinois watersheds. Journal of Hydrology 176: 57-77.

Arnold JG, Fohrer N. 2005. SWAT2000: current capabilities and research opportunities in applied watershed modeling. Hydrological Processes 19: $563-572$.

Arnold JG, Srinivasan R, Muttiah RS, Williams JR. 1998. Large-area hydrologic modeling and assessment: Part I. Model development. Journal of the American Water Resources Association 34(1): 73-89.

Barlund I, Kirkkala T, Malve O, Kamari J. 2007. Assessing SWAT model performance in the evaluation of management actions for the implementation of the Water Framework Directive in a Finnish catchment. Environment Modelling and Software 22: 719-724.

Barron J, Rockström J, Gichuki F, Hatibu N. 2003. Dry spell analysis and maize yields for two semi-arid locations in East Africa. Agriculture and Forest Meteorology 117(1-2): 23-37.

Bastiaanssen WGM, Singh R, Kumar S, Schakel JK, Jhorar RK. 1996. Analysis and recommendations for integrated on-farm water management in Haryana, India: a model approach. Report 118, DLO Winand Staring Center, Wageningen, p. 152.

Calder IR. 1999. The Blue Revolution: Land Use and Integrated Water Resources Management. London: Earthscan.

Chiew FHS, Peel MC, Western AW. 2002. Application and testing of the simple rainfall-runoff model SIMHYD. In Mathematical Models of Small Watershed Hydrology and Applications, Singh, VP, Frevert DK (eds), Water Resources Publications: Littleton, Colorado.

Evenari M, Shanan L, Tadmor NH. 1971. The Negev: The Challenge of a Desert. Harvard University Press: Cambridge, Mass.

Gassman PW, Reyes MR, Green CH, Arnold JG. 2007. The Soil and Water Assessment Tool: Historical development, application and future research directions. Transactions of the ASABE 50(4): 1211-1250.

Heuer B, Nadler A. 2000. Physiological Parameters, Harvest Index and Yield of deficient irrigated cotton. Journal of Crop Production 2(2): 229-239.

Holvoet K, Van Griensven A, Seuntjens P, Vanrolleghem PA. 2005. Sensitivity analysis for hydrology and pesticide supply towards the river in SWAT. Physics and Chemistry of the Earth 30: 518-526.

Immerzeel WW, Gaur A, Zwart SJ. 2008. Integrating remote sensing and a process-based hydrological model to evaluate water use and productivity in a south Indian catchment. Agricultural Water Management 95: 11-24.

IPCC. 2007. Climate change 2007: The physical science basis. Contribution of working group I to the fourth assessment report of the Intergovernmental Panel on Climate Change, Cambridge University Press: Cambridge, United Kingdom and New York, NY, USA; p. 1009. Jalota SK, Sood A, Chahal GBS, Choudhury BU. 2006. Crop water productivity of cotton (Gossypium hirsutum L.)- wheat (Triticum aestivum L.) system as influenced by deficit irrigation, soil texture and precipitation. Agricultural Water Management 84: 137-146.
Joshi PK, Jha AK, Wani SP, Joshi L, Shiyani RL. 2005. Meta-analysis to assess impact of watershed programme and people's participation. Research report no. 8. International Crops Research Institute for the Semi Arid Tropics, Patancheru, India and Asian Development Bank, Manila, the Philippines.

Joshi PK, Jha AK, Wani SP, Sreedevi TK. 2009. Scaling-out community watershed management for multiple benefits in rainfed areas. In Rainfed agriculture: Unlocking the potential, Wani SP, Rockstrom J, Oweis T (eds), The Comprehensive Assessment of Water Management in Agriculture Series, Volume 7, CABI Publishing: Wallingford, UK; pp. $1-310$.

Kannan N, White SM, Worrall F, Whelan MJ. 2007. Sensitivity analysis and identification of the best evapotranspiration and runoff options for hydrological modelling in SWAT-2000. Journal of Hydrology 332 456-466.

Kim NW, Lee J. 2008. Temporally weighted average curve number method for daily runoff simulation. Hydrological Processes 22(25) 4936-4948.

King KW, Arnold JG, Bingner RL. 1999. Comparison of Green-Ampt and Curve number methods on Goodwin Creek watershed using SWAT. Transactions of the ASABE 42(4): 919-925.

Krieg DR. 2000. Cotton water relations. AAES Special Report 198. Proceedings of the 2000 Cotton Research Meeting.

Lal R. 1999. Soil quality and soil erosion. Ankeny, IA: Soil and Water Conservation Society.

Lenhart T, Eckhardt K, Fohrer N, Frede H-G. 2002. Comparison of two different approaches of sensitivity analysis. Physics and Chemistry of the Earth 27: 645-654.

Lu H, Gallant J, Prosser LP, Moran C, Priestley G. 2001. Prediction of sheet and rill erosion over the Australian continent, incorporating monthly soil loss distribution. Technical report 13/01, CSIRO Land and Water.

Luo Y, He C, Sophocleous M, Yin Z, Hongrui R, Ouyang Z. 2008. Assessment of crop growth and soil water modules in SWAT2000 using extensive field experiment data in an irrigation district of the Yellow River Basin. Journal of Hydrology 352: 139-156.

Massuel S, George BA, Gaur A, Nune R. 2007. Groundwater modelling for sustainable water resources management in the Musi Catchment, India. MODSIM-2007, Christchurch, Dec 10-14, 2007.

Molden DJ, Sakthivadivel R, Keller J. 2001. Hydronomic Zones for Developing Basin Water Conservation Strategies. Research Report 56, International Water Management Institute (IWMI): Colombo, p. 30.

Molle F. 2003. Development Trajectories of River Basins-A Conceptual Framework. Research Report No. 72, International Water Management Institute (IWMI): Colombo, p. 31.

Monteith JL. 1965. Evaporation and the environment. p. 205-234. In The state and movement of water in living organisms, XIXth Symposium. Society For Experimental Biology, Swansea, Cambridge University Press.

Muleta MK, Nicklow JW. 2005. Sensitivity and uncertainty analysis coupled with automatic calibration for a distributed watershed model Journal of Hydrology 306: 127-145.

Murdock LW, Frye WW. 1983. Erosion: Its Effect on Soil Properties, Productivity and Profit. Publication AGR-102. University of Kentucky, College of Agriculture, Kentucky.

Neitsch SL, Arnold JG, Kiniry JR, Williams JR, King KW. 2005. Soil and water assessment tool. Theoretical documentation, Version 2005.

Pathak P, Wani SP, Singh P, Sudi R, Rao CS. 2002. Hydrological characterization of benchmark agricultural watershed in India, Thailand, and Vietnam. Global Theme on Agroecosystems Report No. 2. Andhra Pradesh, India: International Crops Research Institute for the Semi-Arid Tropics.

Rao AVRK, Wani SP, Singh P, Ahmed MI, Srinivas K. 2006. Agroclimatic characterization of APRLP-ICRISAT nucleus watersheds in Nalgonda, Mahabubnagar and Kurnool districts. Global Theme on Agroecosystems Report No. 30. Andhra Pradesh, India: International Crops Research Institute for the Semi-Arid Tropics.

Reddy VR, Shiferaw B, Bantilan MCS, Wani SP, Sreedevi TK. 2007. Collective Action for Integrated Watershed Management in Semi-Arid India: Strategic Policy and Institutional Options: Strategic Assessments and Development Pathways for Agriculture in the Semi-Arid Tropics. Global Theme on Institutions, Markets, Policy and Impacts. Policy Brief No 11. Andhra Pradesh, India: International Crops Research Institute for the Semi-Arid Tropics.

Rockström J. 2003. Water for food and nature in drought-prone tropics: Vapour shift in rain-fed agriculture. Philosophical Transactions of the Royal Society B 358(1440): 1997-2009. 
Sahrawat KL, Wani SP, Pathak P, Rego TJ. 2010. Managing natural resources of watersheds in the semi-arid tropics for improved soil and water quality: A review. Agricultural Water Management 97: 375-381.

Schaap MG, Leij FJ, van Genuchten M Th. 2001. Rosetta: a computer program for estimating soil hydraulic parameters with hierarchical pedotransfer functions. Journal of Hydrology 251: 163-176.

Schreider SY, Jakeman AJ, Letcher RA, Nathan RJ, Neal BP, Beavis SG. 2002. Detecting changes in streamflow response to changes in non-climatic catchment conditions: Farm dam development in the Murray-Darling basin, Australia. Journal of Hydrology 262(1-4): L: 84-98.

Schuol J, Abbaspour KC, Srinivasan R, Yang H. 2008. Estimation of freshwater availability in the West African sub-continent using the SWAT hydrologic model. Journal of Hydrology 352: 30-49.

Sharda VN, Dogra P, Prakash C. 2010. Assessment of production losses due to water erosion in rainfed areas of India. Journal of Soil and Water Conservation 65(2): 79-91.

Shemdoe RS, Damme PV, Kikula IS. 2009. Increasing crop yield in water scarce environment using locally available material: An experience from semi-arid areas in Mpwapwa district, Central Tanzania. Agricultural Water Management 96: 963-968.

Shen ZY, Gong YW, Li YH, Hong Q, Xu L, Liu RM. 2009. A comparison of WEPP and SWAT for modeling soil erosion of the Zhangjiachong watershed in the the three Gorges reservoir area. Agricultural Water Management 96(10): 1435-1442.

Shiferaw B, Anupama GV, Nageswara Rao GD, Wani SP. 2002. Socioeconomic characterization and analysis of resource-use patterns in community watersheds in semi-arid India. Working Paper Series no. 12. Patancheru 502 324, Andhra Pradesh, India: International Crops Research Institute for the Semi-Arid Tropics, p. 44.

Shiferaw B, Okello J, Reddy VR. 2009. Challenges of adoption and adaption of land and water management options in smallholder agriculture: Synthesis of lessons and experience. In Rainfed agriculture: Unlocking the potential, Wani SP, Rockstrom J, Oweis T (eds), The Comprehensive Assessment of Water Management in Agriculture Series, Volume 7, CABI Publishing: Wallingford, UK; pp. $1-310$.

Shiferaw B, Rao KPC. 2006. Integrated management of watersheds for agricultural diversification and sustainable livelihoods in eastern and central Africa: Lessons and experiences from semi-arid South Asia. Proceedings of the International Workshop held at ICRISAT, Nairobi, 6-7 December, 2004. Patancheru 502324, Andhra Pradesh, India. International Crops Research Institute for the Semi-Arid Tropics. 53-58. ISBN 92-9066-487-8. Order Code CPE158.

Singh N, Ranade AA. 2009. Climatic and hydroclimatic features of wet and dry spells and their extremes across India. Research Report No. RR-122. Indian Institute of Tropical Meteorology, Pune, India.

Sreedevi TK, Shiferaw B, Wani SP. 2004. Adarsha Watershed in Kothapally, Understanding the drivers of higher impact. Global Theme on Agroecosystems Report No. 10. Andhra Pradesh, India: International Crops Research Institute for the Semi-Arid Tropics.

Sreedevi TK, Wani SP, Sudi R, Patel MS, Jayesh T, Singh SN, Shah T. 2006. On-site and Off-site Impact of Watershed Development: A
Case Study of Rajasamadhiyala, Gujarat, India. Global Theme on Agroecosystems Report No. 20. Andhra Pradesh, India: International Crops Research Institute for the Semi-Arid Tropics.

Srinivasan R, Ramanarayanan TS, Arnold JG, Bednarz ST. 1998. Largearea hydrologic modeling and assessment: Part II. Model application. Journal of the American Water Resources Association 34(1): 91-101.

Tuong TP, Bouman BAM. 2003. Rice production in water-scarce environments. In Water productivity in agriculture: limits and opportunities for improvement, Kijne JW, Barker R, Molden D (eds). CABI Publishing: Wallingford, UK; pp. 53-67.

Ullrich A, Volk M. 2009. Application of soil and water assessment tool (SWAT) to predict the impact of alternative management practices on water quality and quantity. Agricultural Water Management 96: 1207-1217.

Walker B, Salt D. 2006. Resilience thinking. Sustaining ecosystems and people in a changing world. Island Press, pp. 1-174.

Walling DE. 2007. Global change and the sediment loads of the world's river. Proceeding of the $10^{\text {th }}$ International Symposium on River Sedimentation, Moscow, Russia.

Wani SP, Joshi PK, Raju KV, Sreedevi TK, Wilson MJ, Shah A, Diwakar PG, Palanisami S, Marimuthu S, Jha AK, Ramakrishna YS, Sundaram MSS, D’Souza M. 2008. Community watershed as a growth engine for development of dryland areas. A comprehensive assessment of watershed programs in India. Global Theme on Agroecosystems Report No. 47. Andhra Pradesh, India: International Crops Research Institute for the Semi-Arid Tropics.

Wani SP, Pathak P, Jangawad LS, Eswaran H, Singh P. 2003. Improved management of Vertisols in the semi-arid tropics for increased productivity and soil carbon sequestration. Soil Use Management 19: $217-222$.

Wani SP, Ramakrishna YS, Sreedevi TK, Long TD, Thawilkal W, Shiferaw B, Pathak P, Keshava Rao AVR. 2006. Issues, Concept, Approaches Practices in the Integrated Watershed Management: Experience and lessons from Asia. In Integrated Management of Watershed for Agricultural Diversification and Sustainable Livelihoods in Eastern and Central Africa: Lessons and Experiences from Semi-Arid South Asia, Proceedings of the International Workshop held during 6-7 December 2004 at Nairobi, Kenya, pp. 17-36.

Wani SP, Sahrawat KL, Sreedevi TK, Singh P, Pathak P, Rao AVRK. 2007. Efficient rainwater management for enhanced productivity in Arid and Semi-arid drylands. Journal of Water Management 15(2): $126-140$.

Williams JR. 1975. Sediment-yield prediction with universal equation using runoff energy factor. p. 244-252. In Present and prospective technology for predicting sediment yield and sources: Proceedings of the sediment yield workshop, USDA Sedimentation Lab.: Oxford, MS; November 28-30, 1972. ARS-S-40.

Yang D, Kanae S, Oki T, Koike T, Musiake K. 2003. Global potential soil erosion with reference to land use and climate changes. Hydrological Processes 17(14): 2913-2928.

Zwart SJ, Bastiaanssen WGM. 2004. Review of measured crop water productivity values for irrigated wheat, rice, cotton and maize. Agricultural Water Management 69: 115-133. 